\title{
LOS ANTIHÉROES DE KAZAN Y EL CINE MEXICANO DE LOS AÑOS CINCUENTA
}

\author{
Julieta Ortiz Gaitán
}

Una de las presencias más impactantes en la historia del cine norteamericano ha sido, sin duda, la de los grandes rebeldes formados por el cineasta Elia Kazan. Tipos rudos, conflictivos y violentos, echaron por tierra al arquetipo del héroe tradicional portador de los más preciadós valores de la cultura occidental, contenidos en una gallarda presencia física y exaltados con un halo de romanticismo, que hacian suspirar a las mujeres y evocar en los hombres afanes de aventura y heroicidad.

Fue a partir de los años cincuenta cuando estos rebeldes hicieron su irrupción en las pantallas cinematográficas como galanes que rompieron moldes establecidos y, alejándose de sus antecesores, llegaron a convertirse en la imagen del antihéroe.

El cine mexicano, moviéndose desde entonces en la órbita de influencia estadunidense, experimentó cambios significativos en las películas producidas en estos años. A pesar de que la historia rural en sus distintas modalidades no desaparece, el interés por un nuevo tipo de películas se manifestó en argumentos y caracterizaciones propios de un medio urbano y de una emergente clase media, rasgos éstos diferenciales de la sociedad mexicana de aquellos años. La presencia en las pantallas de cine de ídolos como Marlon Brando y James Dean representativos de la crisis de valores sufrida por la generación de la posguerra, dio pauta en México para el surgimiento de actores y actrices jóvenes, casi adolescentes, quienes a imagen y semejanza de los norteamericanos, inundaron el cine con supuestos problemas juveniles.

El presente ensayo se propone establecer las causas de la aparición de estos antihéroes, primero en Estados Unidos y posteriormente en sus epígonos mexicanos, así como intentar deslindar hasta dónde son representativos de los conflictos juveniles de la sociedad de su tiempo, o bien de qué forma influyeron en dicha sociedad, por su mitificación en el cine, con la proliferación de los llamados "rebeldes sin causa". En el caso mexicano es interesante establecer una correlación entre la realidad objetiva y las películas de "rebeldes", para encontrar una posible explicación a la identificación colectiva con estos ídolos, así como determinar cuáles fueron las causas, si las hubo, del descontento juvenil de la generación de los cincuenta. 


\section{Elia Kazan y el Actor's Sudio}

Emigrado de la lejana Estambul, Elia Kazan llegó a Nueva York en 1913 cuando contaba cuatro años de edad, junto con sus padres, como una de tantas familias que arribaron a "hacer la América". Su padre, comerciante griego, pronto se estableció en el negocio de alfombras, bas tante redituable en una ciudad como Nueva York; hombre rudo y de espíritu llano, no fue apto para establecer una relación favorable con el hijo, quien tuvo cierta preferencia por su madre. mujer de más cui. rura y sensibilidad. Esta imagen paterna probablemente inspirará más tarde al personaje puritano y rígido que rechaza a su hijo en el filme Al Fste del Paraiso. Kazan confiesa que fue su madre la figura decisiva en los años de su infancia y adolescencia, debido a la persuasiva dirección que ésta ejerció hacia intereses más elevados, convencida como estaba de la necesidad de extraer al hijo del medio en que vivían.

Como todo inmigrante, el joven experimentó la difícil ambigüedad de su nueva vida: por un lado, la segregación voluntaria de la familia, principalmente de los miembros mayores, contrastando con el deseo de los jóvenes de integrarse al nuevo entorno social.

Matriculado en Yale, Kazan inició sus estudios de arte dramático ingresando al "Group Theatre", dirigido entonces por Lee Strasberg y Harold Clurman, experiencia que habría de ser decisiva en su formación teatral. En 1941 se trasladó a Hollywood para iniciar su prolífica trayectoria cinematográfica dirigiendo, tres años después, su primera película y alternando sus actividades como director de teatro en Broadway,

Visualizando la necesidad de formar un grupo teatral de intercambio experimental y teórico que continuase la labor del desaparecido "Group Theatre", Kazan creó en el año de 1947 el "Actor's Studio" en Nueva York, al lado de Cheryl Crawford y Robert Lewis, donde se formó toda una generación de actores que revolucionarian las técnicas interpreta. tivas y la imagen del galán de Hollywood.

El "Actor's Studio" estaba regido por el famoso "Método" basado en los principios de Stanislavsky, aplicado en ejercicios que consistían, fundamentalmente, en "... el desarrollo de las sensaciones, de la imaginación, de la espontaneidad, de la fuerza del actor y, por encima de todo, la estimulación de sus posibilidades emocionales..." 1

I Michel Ciment, Elia Kazan por Elia Kazan..., op. cit, p. 54. 
Pronto Lee Strasberg, el antiguo maestro, fue llamado a colaborar en el Studio, quedando al frente del célebre espacio de experimentación cuando, en 1954, Kazan relegó su actividad teatral para dedicarse de lleno al cine.

Algunos de los actores y actrices que pasaron por el Studio fueron Julie Harris, Kim Hunter, Karl Malden, Anthony Quinn, Rod Steiger, Shelley Winters, Marilyn Monroe, Warren Beatty, Paul Newman, Montgomery Clift y los mencionados Marlon Brando y James Dean.

Fue con la obra del autor teatral Tennessee Williams, A Streetcar named Desire (Un Tranvia llamado Deseo) que Kazan llevó al cine, con la que introdujo la imagen agresiva de un actor desconocido quien la había representado en Broadway durante largo tiempo: Marlon Brando El debut cinematográfico de Brando proyectó en la pantalla una recia personalidad llena de magnetismo así como una impecable actuación que le permitió, en el papel de Stanley Kowalski, el prosaico y sensual polaco, desplegar al máximo sus posibilidades histriónicas bajo la hábil dirección de Kazan.

Al año siguiente, 1952, realizaron la segunda cinta de la trilogía KazanBrando con ¡Viva Zapata! llevando como compañero en el reparto a Anthony Quinn en el papel de Eufemio Zapata, actuación que le valió un óscar de la Academia.

Pero fue en 1954 con el filme $O n$ the Waterfront (Nido de Ratas). cuando Brando se convirtió en el arquetipo del antihéroe kazaniano: rudo y tierno a la vez; inconforme, tempestuoso, de escasas palabras, mirada intensa, ademanes peculiares y una gran tensión contenida presta a estallar en cualquier momento (ver apéndice 1).

\section{Los antihéroes: un nuevo tipo de galán}

Desde las miradas fulminantes de Rodollo Valentino hasta la sonrisa seductora de Clark Gable, las actitudes con que los héroes tradicionales afrontaban peligros, resolvían problemas, peleaban con arrojada intrepidez y enamoraban con un beso - dado de perfil a la cámara- a una siempre frágil heroína, eran de altruismo, de nobleza y desinterés, al servicio de causas nobles o de valores establecidos. En los filmes de aventuras, donde el héroe romántico se despliega al máximo, esta actitud persiste, pese a eventuales ligerezas y a cierta elasticidad en cuestiones morales. 
Defensores de causas justas, de los débiles y, por supuesto, de las mujeres - un poco a la manera de los caballeros medievales- estos actores desfilaron por las pantallas cinematográficas haciendo vibrar a un público emocionado que veía en ellos adalides modernos. Empezando por los grandes y, cronológicamente, primeros amantes: John Barrymore, Ramón Novaro, John Gilbert, Leslie Howard, Ronald Colman, Lewis Stone, Douglas Fairbanks (padre e hijo), Lawrence Olivier -quien obtuvo el título de Sir por su actuación en Hamlet-y el aventurero por excelencia Errol Flynn. Están también los primeros "xudos", antecesores de los antihéroes, como Humphrey Bogart, Glenn Ford, Robert Mitchum y Victor Mature. En la decantada epopeya del oeste, narrada por una serie de clichés fílmicos que darían paso al género del western, surgirían una serie de héroes muy ad hoc con la mentalidad norteamericana colonizadora, expansiva y puritana: el héroe WAP (white-anglosaxon-protestant) como portador del "bien de la civilización" en un medio "salvaje" y hostil. Hombre de una sola pieza, sin dudas respecto a sus convicciones, sin conflictos ni cuestionamientos, sencillos y sanos como James Stewart, Henry Fonda, Alan Ladd, John Wayne y el insobornable Gary Cooper, la imagen de la integridad.

Estaba asimismo el galán mundano, con mucho savoir faire y encanto europeo: elegante, jet-setter y solterón inconquistable, como Charles Boyer, William Holden, Gregory Peck, Curt Jurgens, John Derek, Tony Curtis, Mel Ferrer, a veces Rock Hudson, quizá Ray Milland, el très chic Louis Jourdan y el incomparable Cary Grant, galán por antonomasia de este género. Y por último los grandes aventureros, por lo general también grandes amantes, de la pantalla cinematográfica: Tyrone Power, Stewart Granger, Kirk Douglas, Clark Gable, Robert Taylor, Burt Lancaster, el mencionado Tony Curtis y tantos otros. Algunas de sus caracterizaciones ya son clásicas del cine estadunidense de la época dorada de Hollywood: Robert Taylor como Armando, al lado de Greta Garbo en La Dama de las Camelias; Stewart Granger en Scaramouche como André Morcau, con Eleanor Parker y Janet Leigh, quien sostiene uno de los duelos de esgrima más espectaculares del cine encontra del aristocrático Mel Ferrer; el mismo Granger en Las Minas del Rey Salomón y en El Prisionero de Zenda, ambas cintas al lado de Deborah Kerr; en Beau Brummell, como árbitro de la elegancia de la corte inglesa, enamorando a Elizabeth Taylor; también está Tyrone Power en sus apasionadas interpretaciones de héroes hispanos, como en Un Capitán de Castilla y en Sangre y Arena al lado de Rita Hayworth; para terminar con Clark Gable, "El rey", for- 
mando pareja perfecta con Vivian Leigh, en el papel del inolvidable Reth Buttler de Lo que el Viento se Llevó.

Huelga decir que esta antología de galanes responde a preferencias propias y que, por tanto, conlleva grandes dosis de subjetividad; sin embargo, se puede llegar a criterios uniformes en cuanto a la enorme importancia que, tuvieron, en la historia del cine norteamericano, actores como Taylor, Granger, Power y Gable.

Estos caballeros de la pantalla no tenían edad, o mejor dicho, representaban esa etapa dorada en la vida de todo hombre cuando, a los bríos de la lozana juventud, se agrega la sabiduría que da la experiencia de la madurez. En este sentido, son personajes en la plenitud de la vida que no manifiestan una edad definida, sino que simplemente están en los mèjores años de su existencia.

Pero a partir de los años cincuenta el panorama social cambiará esta imagen masculina de heroísmo por otra que habrá de expresar plenamente los conflictos y contradicciones de la época: el "muchacho bueno" ya no contará siempre con la simpatía de todos sino que, por el contrario, he aqui que el tortuoso, el rebelde, el que presenta rasgos de villano, va a convertirse en el protagonista principal y, para sorpresa de muchos, en una nueva especie de héroe.

Empeñado en revolucionar las técnicas teatrales contra una tradición "heroica, romántica y retórica", ${ }^{2}$ Elia Kazan creó en el "Actor's Studio" una caracterización masculina definitivamente menos "charming" pero más humana e impactante. Actores como Marlon Brando, James Dean, Montgomery Clift, Warren Beatty, Paul Newman, Sal Mineo, y en menor grado Andy Grifith y John Garfield, representan a estos héroes silenciosos, con problemas para expresar sus sentimientos, en contra del mundo que los rodea, de una gran ternura interna contenida por una apariencia impasible y hostil.

Puede decirse que la actuación de estos actores se caracterizaba por una expresividad corporal muy elocuente por medio de actitudes y ademanes peculiares, así como por el empleo de los grandes contrastes como recurso escénico: de una inmovilidad absoluta a la más desatada violencia; de un silencio inmutable a gritos desgarradores; de una crueldad inconmovible a la más indefensa ternura. Fuertes y débiles a la vez, estos niños-hombres demostraban cierta dualidad en sus inclinaciones amorosas: como galanes eran rudos, desaprensivos y en ocasiones bruta-

2 “... le qui compte dans la Méthode, c'est la révolte contre le théatre héroique, romantique, thetorique ..." Roger Tailleur, Elia Kazan ... , op. cit., p. 126 
les, caparazón que encubría una sensibilidad a flor de piel propia de un temperamento tímido y edípico.

Elia Kazan se expresaba de Marlon Brando y Jamen Dean -los máximos exponentes del género- en los siguientes términos:

Pienso que él (James Dean) tenía una cara muy poética, un rostro bello y muy doloroso. En los primeros planos se percibía todo este dolor. Siente uno tanta pena hacia él cuando se le ve en primer plano; pero me daba cuenta de que su cuerpo tenía muchas cualidades; era incluso más expresivo en la libertad de movimientos que el de Brando, en el de éste había demasiada tensión. Brando tenía una tensión aterradora, pero tiene una inmensa capacidad para quedarse inmóvil. $Y$ sus movimientos son magníficos - Brando es un genio- pero Dean tenía un cuerpo lleno de vida del que me serví mucho en los planos largos... ${ }^{3}$

Otra innovación de estos actores fue la caracterización de los adolescentes y su mundo privado, particularmente en el caso de Dean, hecho que habría de causar un fenómeno de identificación colectiva pocas veces visto en la historia del cine ${ }^{4}$

\section{De "El salvaje" a "Esplendor en la hierba"}

En el verano de 1947, una banda de motociclistas vagabundos llegó al calmado pueblo de Hollister, California. Después de beber cerveza y escandalizar un poco, sus integrantes se dedicaron a cometer actos vandálicos de verdadera violencia. Cuando los hechos aparecieron en los periódicos, el guionista cinematográfico John Paxton tuvo la idea de llevarlos a la pantalla en un filme de crítica social que cuestionara el surgimiento de estas pandillas nómadas de jóvenes alienados, frecuentes en los años que siguieron al fin de la Segunda Guerra Mundial. 5

El resultado fue un filme polémico y novedoso: The Wild One (El Salvaje) realizado en 1953 y dirigido por Laslo Benedek, quien llamaria para el papel principal masculino al triunfador de $A$ Streetcar named Desire: Marlon Brando. La intención implícita de la cinta era la del análisis social pero, sin proponérselo, creó un aura de romanticismo

3 Michel Ciment, op. cit., p. 190.

4 Raymond de Beckex, "James Dean, un ejemplo de identificación colectiva", en Novedades, México en la cultura, núm. 441, septiembre 20, 1957.

5 Douglas Brode, The Films of the Fifties ..., op cit., p. 86 
alrededor de los protagonistas y su violento proceder. Douglas Brode, en su libro The Films of the Fifties afirma que: "... habia una mística innegable en las chamarras de piel negra, en la 'jerga' de su hablar y en la fanfarrona arrogancia de estos alienados busca-pleitos..." 6

De tal manera, se iniciaba una interrelación entre la realidad y la ficción cinematográfica debida, en parte, a la convincente y carismática caracterización de Brando como "Johnny", el jefe de la banda, cuya imagen sobre una motocicleta y con una calavera en la espalda, se convertiría en el símbolo de la rebeldía juvenil.

En una escena de la película, mientras él y sus muchachos beben cerveza en una taberna a la oxilla de la carretera, alguien le pregunta: "¿Contra qué se rebelan ustedes?", a lo que Johnny, con un soberbio e indiferente encogimiento de hombros, responde: "¿Qué propones?" (Aunque el sentido de la frase en inglés - "What've you got?"- se pierde en la traducción al español, ya que literalmente significa: "¿Qué tienes?" esto es, qué convicciones o postulados tienes para rebelarme contra ellos). En esencia, Johnny está afirmando que se encuentra dispuesto a rebelarse contra todo, sea lo que fuere. Con ello Brando se convirtio en el portavoz de la llamada Beat Generation o beatniks, generación que, como se verá, nació en el vacío espiritual de la posguerra.

Después de The Wild One, Brando magnificó el personaje de Johnny en On the Waterfront (Nido de Ratas), bajo la dirección de Elia Kazan en el año de 1954, esta vez enclavado en el ambiente sórdido y violento de los muelles de Manhattan. "Terry Malloy", quien aspira a convertirse en boxeador profesional, es hermano de importante personaje del hampa, Rod Steiger, por lo que se ve coartado en su vida cotidiana y en la realización de sus aspiraciones. Corteja, muy a su modo, a otra integrante del "Actor's Studio": Eve Marie Saint, heroína de un galán muy especial.

En 1955, la Metro Goldwyn Meyer volvió a tratar el problema de la delincuencia juvenil en Blackboard Jungle, cinta que en México se llamó Semilla de Maldad, dirigida y escrita por Richard Brooks, con las actuaciones de Glenn Ford como el maestro de la High School "jungle"; Anne Francis, su esposa; Louis Calhern, Margaret Hayes, Basil Ruysdoll, Warner Anderson y Sidney Poitier.

La historia se desarrollaba en torno a una escuela secundaria en un pequeño poblado de Estados Unidos y las vicisitudes de un joven maes-

Ibidem, p. 87 . 
tro enfrentado a unos alumnos adolescentes con visos claros de delincuentes. Dado que el principal antihéroe, Warner Anderson, no pudo ir más allá de la simple imitación de Brando, la crítica elogió la actuación de Poitier, permaneciendo aquél como un actor sin relevancia.

La novedad de la cinta consistió en añadir un elemento que sería más tarde inseparable de la imagen de los "rebeldes sin causa"; Bill Haley y sus Cometas ejecutaban la música tema, "Rock around the Clock", en México "Al compás del Reloj", que causaría gran impacto entre la juventud y seria el primer paso en la vasta cultura del rock desarrollada hasta la fecha.

Ese mismo año la Warner Bros., filmó East of Eden dirigida por Elia Kazan, quien llamó a dos de los actores del Studio para los papeles este.. lares: Julie Harris y el debutante James Dean. Basada en la novela de John Steinbeck, el guionista Paul Osborn adaptó una historia sencilla acerca de un adolescente atormentado por sus propios impulsos y porel rechazo que siente de su padre. Dentro de un ambiente puritano, las pasiones estallan más violentas cuanto más reprimidas, dentro de esquemas morales rígidos propios de las familias emigrantes a la costa de California, en tiempos de la Primera Guerra Mundial

Con la Biblia de trasfondo, la historia evoca la rivalidad de Caín y Abel en fraticida lucha por el amor de su padre, un laborioso y recto granjero llamado significativamente "Adán Trask". "Aarón Trask" -Abel- cuenta con la simpatía de todos y con el amor de una novia de infancia; "Cal Trask", por el contrario, lucha consigo mismo y contra un mundo que le es indiferente y hostil, buscando en el fondo, el cariño y la aceptación de sus semejantes.

James Dean interpreta a Cal Trask hasta que se convierte - a la manera de Stanislavsky - en Cal Trask. Sus dudas, sus anhelos, su ansiedad de ser amado, su violencia sin maldad, su ternura y su orfandad materna, son compartidos a la vez y por partes iguales entre el actor y el personaje. Se "metió en la piel" de Cal Trask sin trabajo alguno ya que Dean en realidad era un muchacho granjero nacido en Indiana, huérfano de madre a los nueve años y separado de su padre al contraer éste nuevas nupcias. Después de una infancia al lado de unos tíos y de una adolescencia igual a la de cualquier joven estadunidense, Dean se trasladó a Nueva York a probar fortuna y, siguiendo sus inclinaciones histriónicas, acudió al mítico "Actor's Estudio" de Elia Kazan.

Al Este del Paraiso fue la primera cinta de la trilogía deaniana y James Dean la segunda figura en la línea de Brando, pero no por ello 
menos auténtica ni afortunada: la fama de Dean habría de alcanzar alturas insospechadas y, aunque en un principio la crítica lo comparó con Brando, su gran capacidad interpretatvia así como su gran carisma, aunados a una muerte prematura, lo convirtieron en mito de la juventud "descarriada", 7

Dean crearía este arquetipo de adolescente en la siguiente cinta que filmó, también para la Warner Bros., y en el mismo año de 1955: Rebel without a Cause (Rebelde sin Causa), dirigida por Nicholas Ray y con Nathalie Wood como "Judy", entonces con dieciséis años de edad. Ray, quien fuera ayudante de dirección de Elia Kazan en la cinta $A$ tree grows in Brooklyn, recreó en su filme el contexto social de los estratos acomodados norteamericanos, cuyos miembros más jóvenes debían ser supuestamente "buenos muchachos". Es interesante lo que al respecto anota Douglas Brode:

...Al principio se parecen tanto a los delincuentes juveniles de Blackboard Jungle, pero ése no es el caso: comparados con los muchachos escuálidos y de baja extracción de ese film, éstos son todos muchachos "bien nacidos" de padres que viven en los suburbios de los Ángeles pertenecientes a una clase media alta. . . 8

$Y$ en eso estriba una de las diferencias más significativas del filme, en el tratamiento de una problemática cotidiana común a las clases medias donde, aparentemente, no existe "causa" alguna para que estos jóvenes trasgredan por insatisfacción, cánones familiares, morales y sociales.

El guionista Stewart Stern narra la historia de un joven - "Jim Stark"hijo único, quien acaba de mudarse junto con sus padres a un barrio residencial, y sus peripecias al entablar amistad con una pandilla de adolescentes, que resultan sus compañeros en la nueva escuela a la que asiste. El jefe de la banda, "Buzz", lo provoca constantemente máxime que su novia vive al lado de Dean y ha trabado amistad con él. Después de un enfrentamiento con navajas y cadenas frente al planetario escolar, se concerta una cita para un "chicken jump" esa misma noche, a llevarse a cabo entre Buzz y Jim. Esta práctica, que determinaba cuál de los dos jóvenes era un "gallína", consistía en enfilarse en sendos automóviles robados, hacia un barranco o despeñadero sobre el mar, acelerar al máxi. mo de velocidad para brincar fuera del auto en el último momento sobre

\footnotetext{
T T. 'T. Thomas, I, James Dean, The real story behind America's most popular idol ..., pasim.

8 Douglas Brode, op cit., p. 165.
} 
tierra firme: quien brincara primero resultaba un "cobarde" y el otro, por lo tanto, era el vencedor. Animados por la Wood -quien en el fondo también estaba en disputa- y por el resto de la pandilla, ambos adolescentes inician la carrera y al atorarse la chamarra en la portezuela del coche, Buzz cae al vacío encontrando la muerte. Todos huyen asustados y esa noche, Jim, Judy y Plato (Sal Mineo) buscan en sus respectivos hogares la comprensión y el consejo de sus mayores.

El enfrentamiento de Dean con sus padres simboliza la imposibilidad de comunicación y el abismo generacional abierto entre padres e hijos: una madre dominante, absorbente y rígida frente a un padre débil, indeciso y conformista, incapaz de proporcionar a su hijo la imagen masculina adecuada para su identificación. Ray establece estos planteamientos por medio de metáforas visuales convincentes cuando, en esta escena de la discusión familiar, coloca a los personajes en la escalera de la casa, la madre en la parte superior, Jim en el medio y por último el padre al pie de la escalera, vistiendo un delantal de cocina ya que previamente preparaba la cena. En este atuendo, resulta patética la imagen visual cuando Dean le pregunta al padre: "Papá, ¿cómo se llega a ser hombre?"

No encontrando en sus hogares ningún apoyo, los tres jóvenes deciden esconderse en una casona abandonada donde momentáneamente, juegan a integrar una familia. Cercados por la policía, Plato es presa de gran nerviosismo e intenta huir paxa caer abatido por las balas de un patrullero. Esta tragedia sucede después de que Jim había tratado con la policía, por medio de magnavoces, una entrega pacífica que garantizara sus vidas. Al lado del cadáver de su amigo, Jim llora abrazado de su padre quien promete "no fallarle otra vez" y se aleja con su amiga Judy.

Rebelde sin causa, cinta que dio nombre a toda una generación, refleja la problemática social de su tiempo en un modo coherente y veraz, cumpliendo así con algunas de las finalidades del cine: comunicación, testimonio, interpretación y expresividad, por lo que puede ser considerada como paxámetro para el análisis de las películas mexicanas del mismo género.

La última película filmada por James Dean, Gigante, dirigida por George Stevens y basada en la novela de Edna Feber, presenta en la primera parte una actuación similar, por parte de Dean, a sus dos anteriores películas. Un joven texano, "Jett Rink", peón en un emporio ganadero del hacendado "Bick Benedick" -Rock Hudson-lucha y se esfuerza por salir de la situación precaria en que vive. Por un golpe de fortuna -unos terrenos heredados por la hermana de Benedick - se convierte en un magnate petrolero quien puede tenerlo todo menos el amor de la 
mujer que ama. Jett Rink aparece al final de la película como un hombre de edad avanzada, borracho y fracasado, actuación que puso en evidencia la versatilidad de la que era capaz el joven Dean.

Gigante trata el escabroso problema de la discriminación de que son objeto los mexicanos en el Estado de Texas, desde las villas miserables. en que habitan los peones de Bick Benedick hasta el conflicto familiar que ocasiona el hijo de Benedick al contraer nupcias con una mexicana (Elsa Gárdenas). El problema es tratado con crudeza y realismo, sin embargo la censura cinematográfica puso en evidencia su estrechez de criterio al mutilar de una forma lamentable la cinta de Stevens. El resultado fue que lo exhibido en las salas de México fue una sucesión de imágenes sin coherencia ni sentido, con el afán de "tapar el sol con un dedo". Es importante lo que se publicó en México en la cultura, en agosto de 1957:

... Existe, por otra parte, un error: considerar denigrante para México la exhibición de la realidad que nadie puede ocultar... Para México no es una vergüenza que discriminen a sus hijos, sino que haya mexicanos que se arrepientan de serlo o que pretendan ocultar, disfrazar y suprimir los medios -en el ejemplo de Gigante de procedencia norteamericana- que denuncian o exhiben algunos de los padecimientos de nuestros compatriotas o sus descendientes...

Pocos días después de terminada la filmación de Gigante, James Dean se dirigia en su auto deportivo, un porsche spyder, rumbo a Salinas, California (donde se rodó East of Eden) para participar en una carrera automovilística, cuando encontró la muerte al Ilegar al lugar llamado Paso. Robles, el 30 de septiembre de 1955.

El ciclo kazaniano de cintas de antihéroes se cierra con la realización de otra historia vigorosa y conmovedora como fue Splendor in the Grass (Esplendor en la hierba) rodada en 1961 , con las actuaciones de Nathalie Wood y Warren Beatty. Este último, en su papel de "Bud Stamper", personifica de nueva cuenta al adolescente atrapado en una problemálica social y ontológica, imposibilitado para enfrentar la realidad hostil y en constante enfrentamiento con un padre convencional e inflexible. En este film, al igual que en Al este del paraiso, Kazan nos muestra la asfixiante moral pequeño-burguesa de un pueblo estadunidense de los años treinta. Resultado de esta represión es la reclusión en un sanatorio.

- Novedades, México en la cultura, núm 438, agosto $21 \mathrm{de} 1957$ 
psiquiátrico para Nathalie y la aveniencia a una vida mediocre y conformista por parte de Beatty.

Éste es en general el panorama de los films norteamericanos en la década que va de 1951 a 1961, en los cuales aparecieron estos galanes rebeldes tormados en el Studio de Elia Kazan a quienes llamo antihéroes. Veamos qué pasaba en el cine mexicano.

\section{El cine mexicano y sus galanes antes de los años cincuenta}

Según material fotográfico consultado en la Historia documental del cine mexicano, de Emilio García Riera, los galanes del cine mexicano anteriores a los años cincuenta, correspondían por lo general, a los siguientes tipos:

1. El charro u hombre de campo, vestido a la usanza charra o como simple campesino;

2. El galán citadino, vestido con traje y corbata, a veces sombrero; cuando más mundano, usa smocking;

3. El galán humilde, tenorio de barriada;

4. Los galanes de carácter, como toreros, militares, espadachines, etcétera.

A1 igual que los galanes de Hollywood, estos actores representaban hombres de edad madura $\rightarrow 0$ al menos su apariencia era tal- y no se había presentado en las pantallas la intervención de los más jóvenes. A esto comenta el mencionado García Riera:

... Como tantas veces, los estudiantes del cine nacional (recuérdese a Enrique Herrera, Luis Aldás, etcétera) podían ser encarnados por cuarentones (Andy Russel y Resortes). ${ }^{10}$

Entre estos galanes podemos recordar a Tito Guízar, Fernando y Domingo Soler, el otoñal Arturo de Córdova, Emilio Tuero, Alfonso Ortiz Tirado, David Silva, René Cardona, Antonio Badú, Abel Salazar, José María Linares Rivas, Armando Calvo, Rubén Rojo, Víctor y Tito Junco y tantos otros.

10 Emilio García Riera, Historia documental del cine mexicano.., op cit, $t$, vI, p. 99 . 


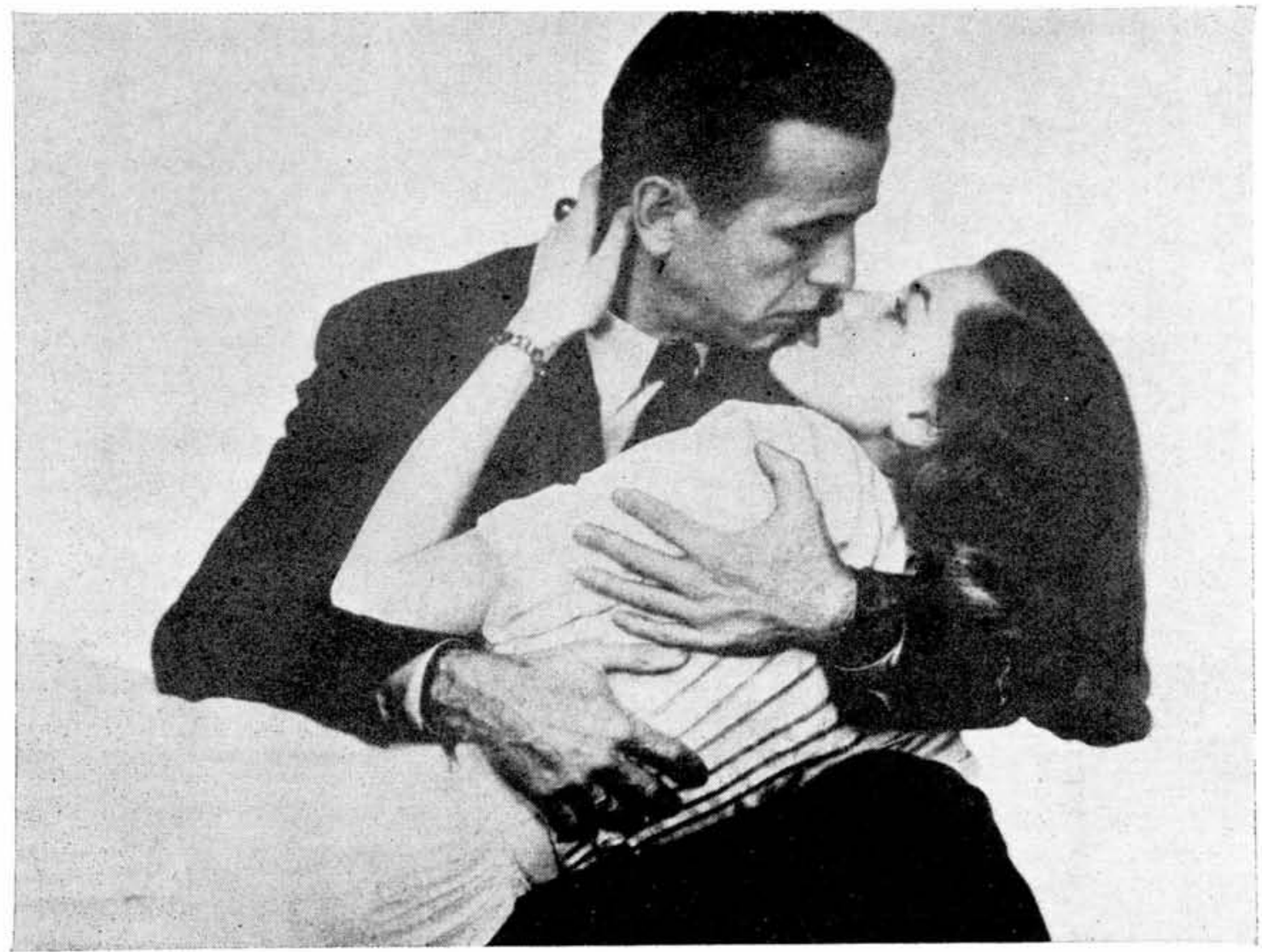

Figura 1. “... Enamoraban con un beso - dado de perfil a la cámara- a una siempre frágil heroina..." En la foto Humphery Bogart y Lauren Bacall en The Big Sleep (1946). 
DOI: http://dx.doi.org/10.22201/iie.18703062e.1986.55.1267

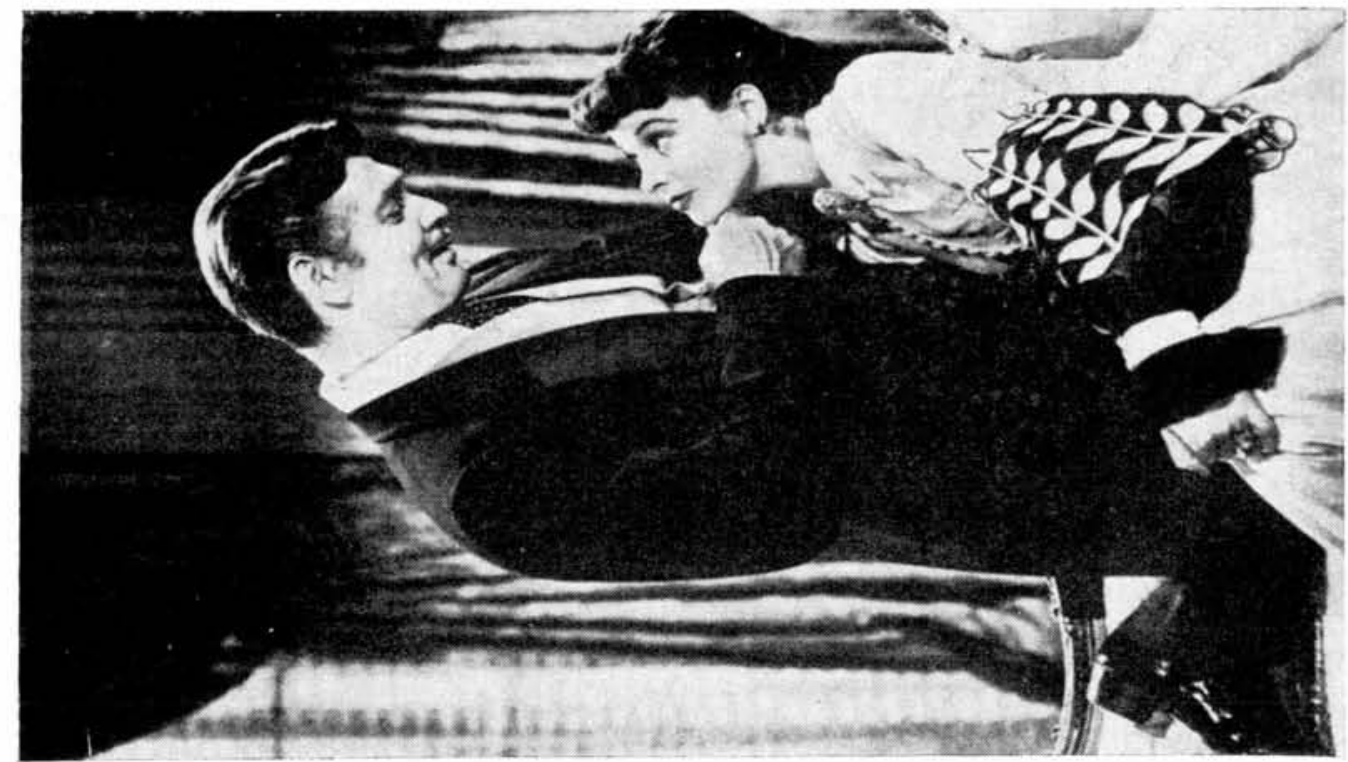

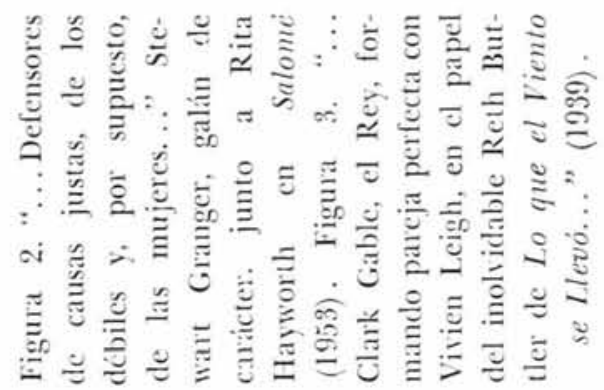

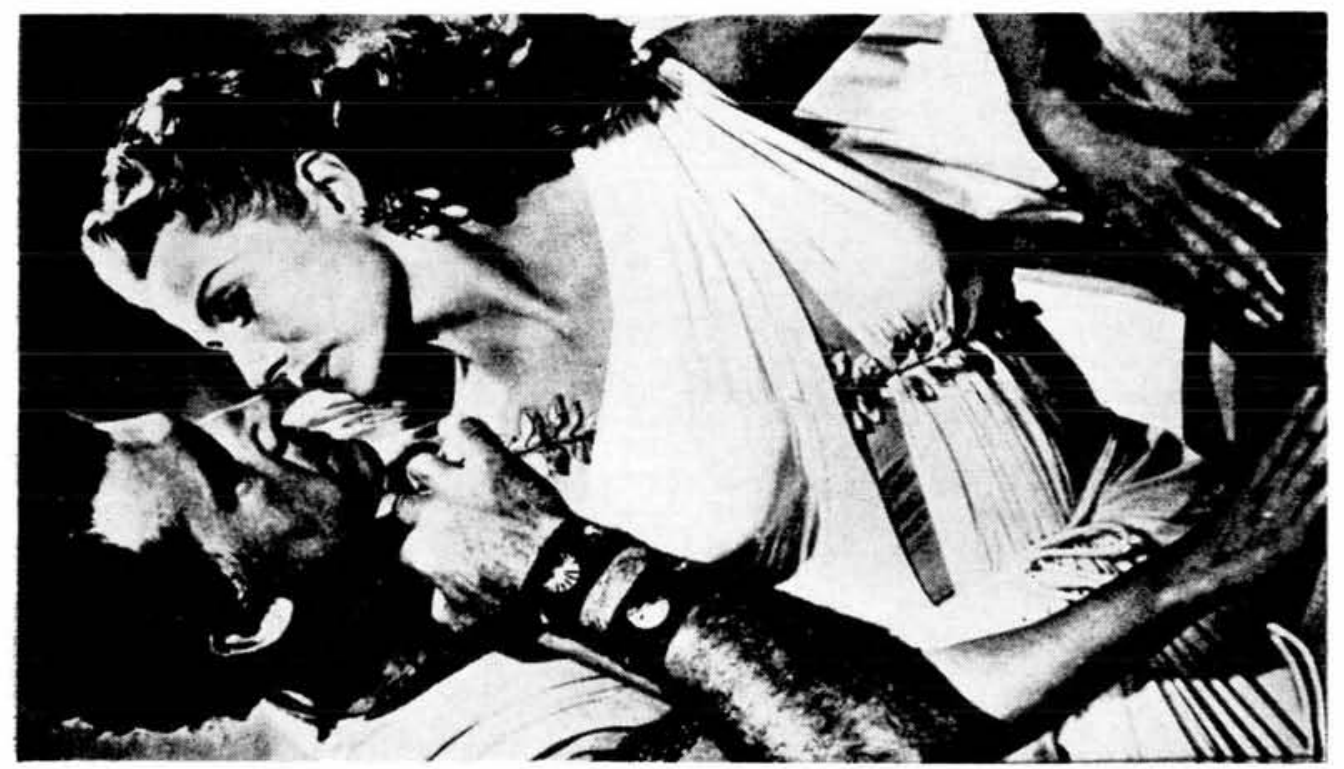




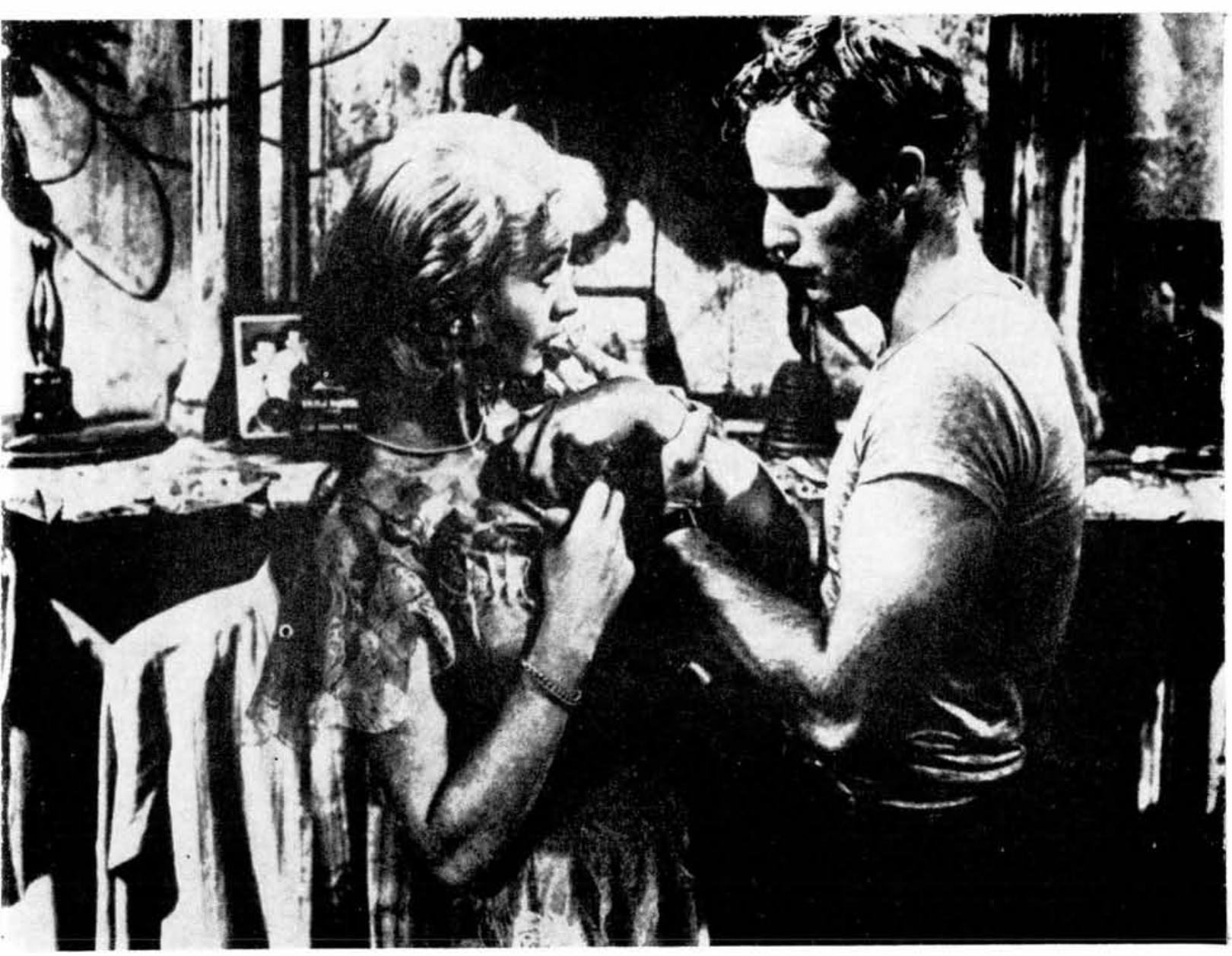

Figura 4. “... El tortuoso, el rebelde, el que presenta rasgos de villano, va a convertirse en el protagonista principal..." Marlon Brando con Vivien Leigh en Un Tranvia Llamado Deseo (1951). 
DOI: http://dx.doi.org/10.22201/iie.18703062e.1986.55.1267

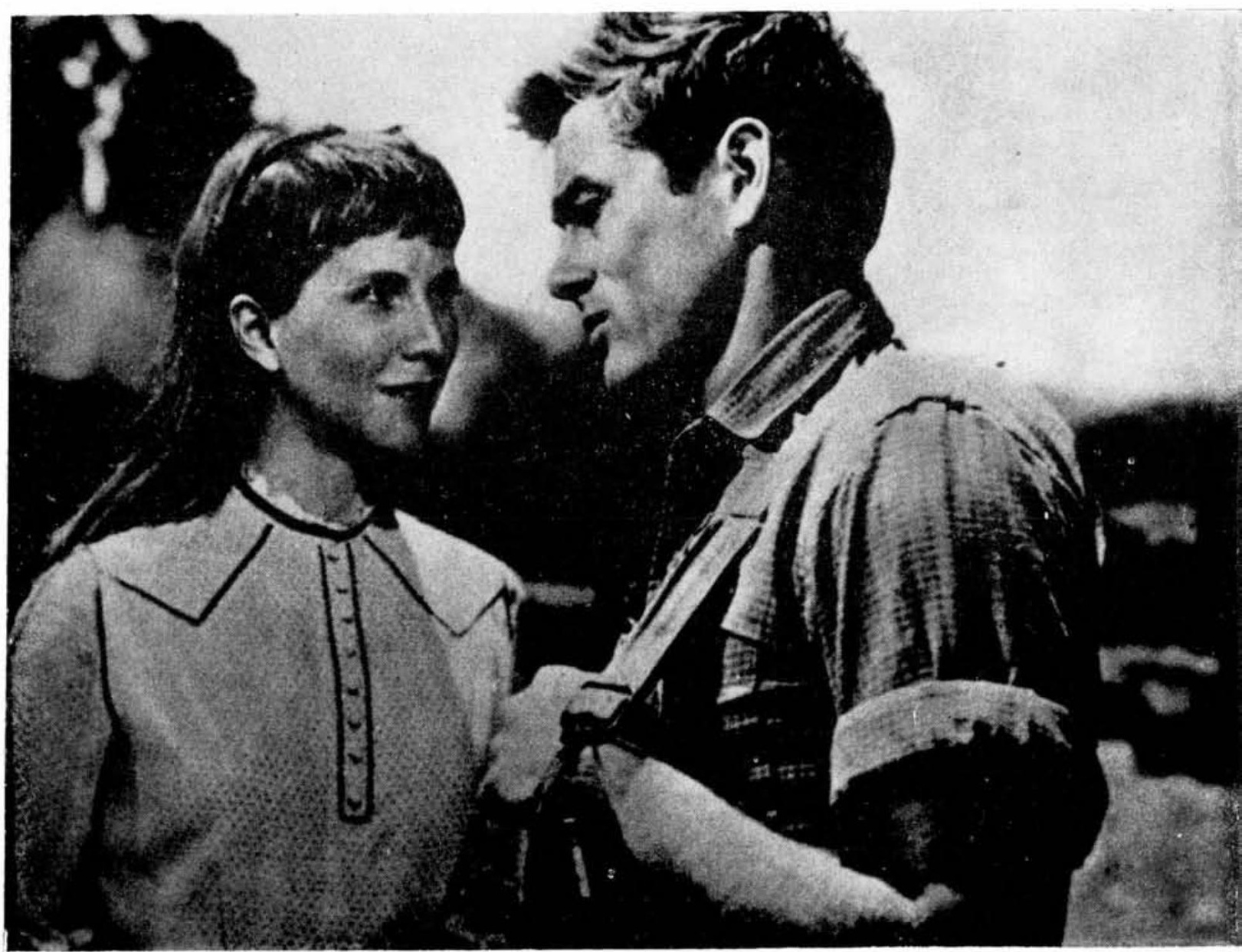

Figura 5. “...Una caracterización masculina definitivamente menos charming pero más humana e impactante..." Escena de Al Este del Paraiso con Julie Harris y el debutante James Dean (1955). 
DOI: http://dx.doi.org/10.22201/iie.18703062e.1986.55.1267

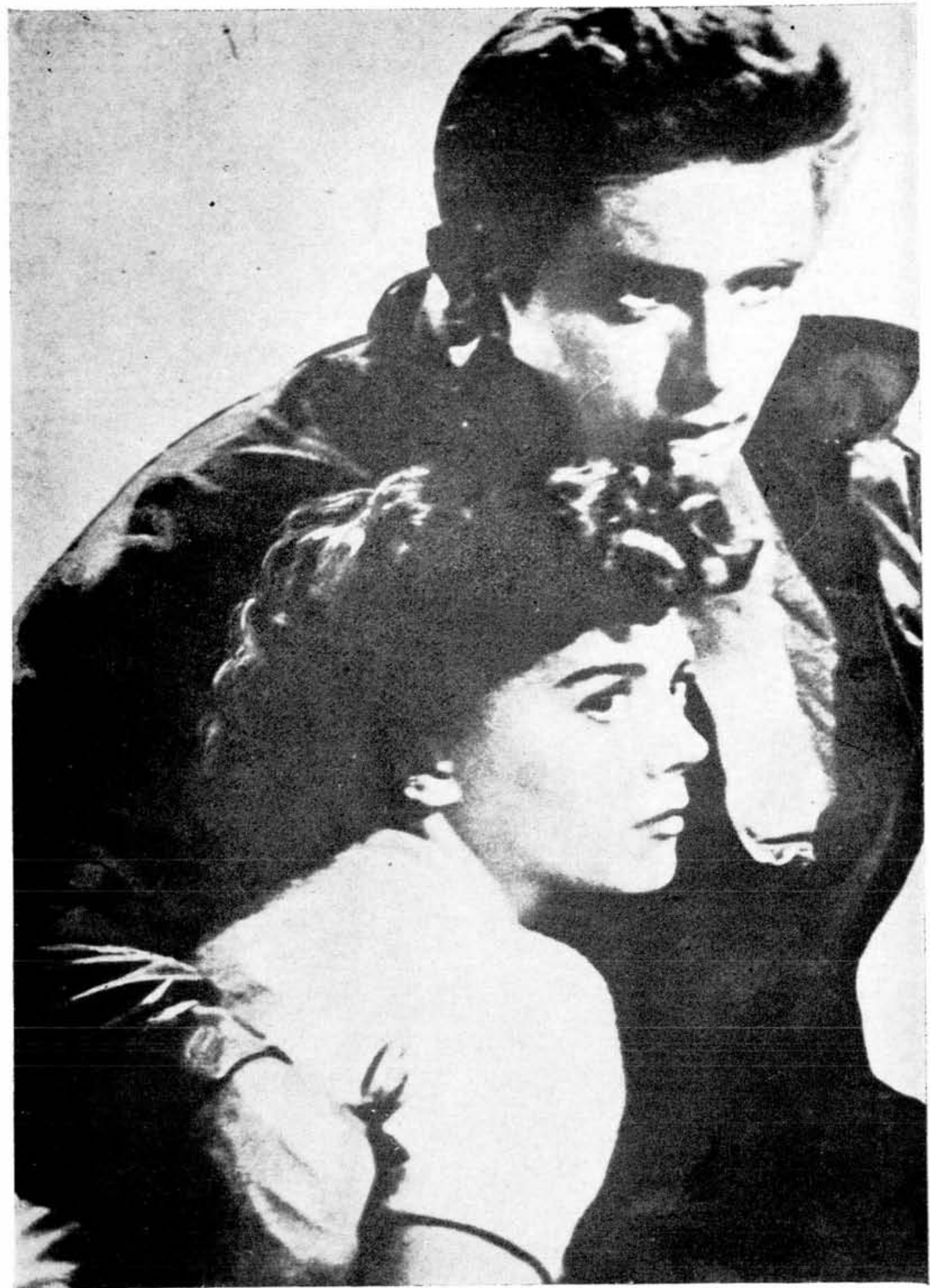

Figura 6. "... Rebelde sin Causa, cinta que dio nombre a toda una generación..." James Dean y Nathalie Wood, una nueva imagen de pareja cinematográfica (1955). 


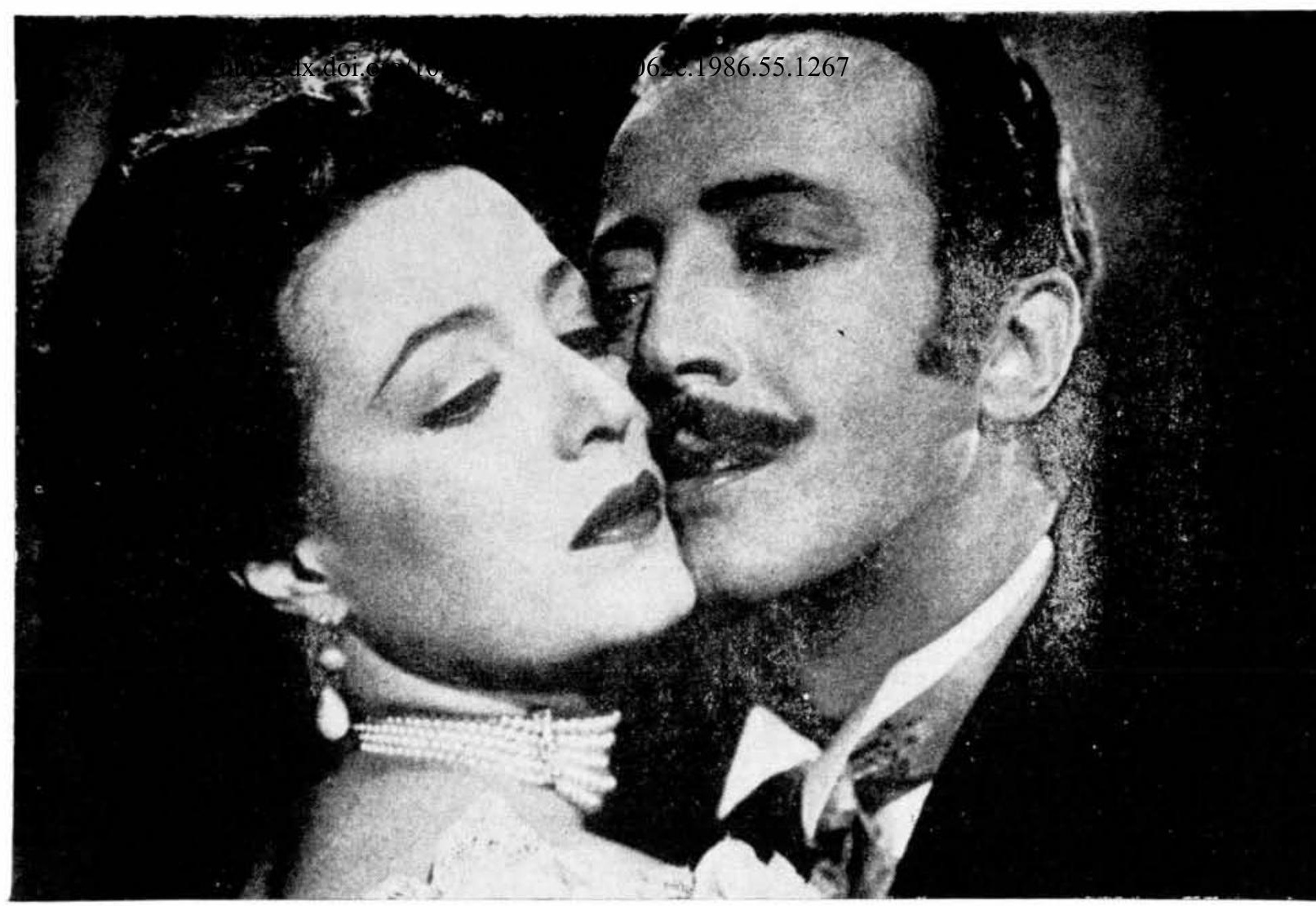

Figura 7. “... Entre los cuales también predominó el héroe romántico tradicional..." En la foto María Félix y Emilio Tuero en Vértigo (1946).

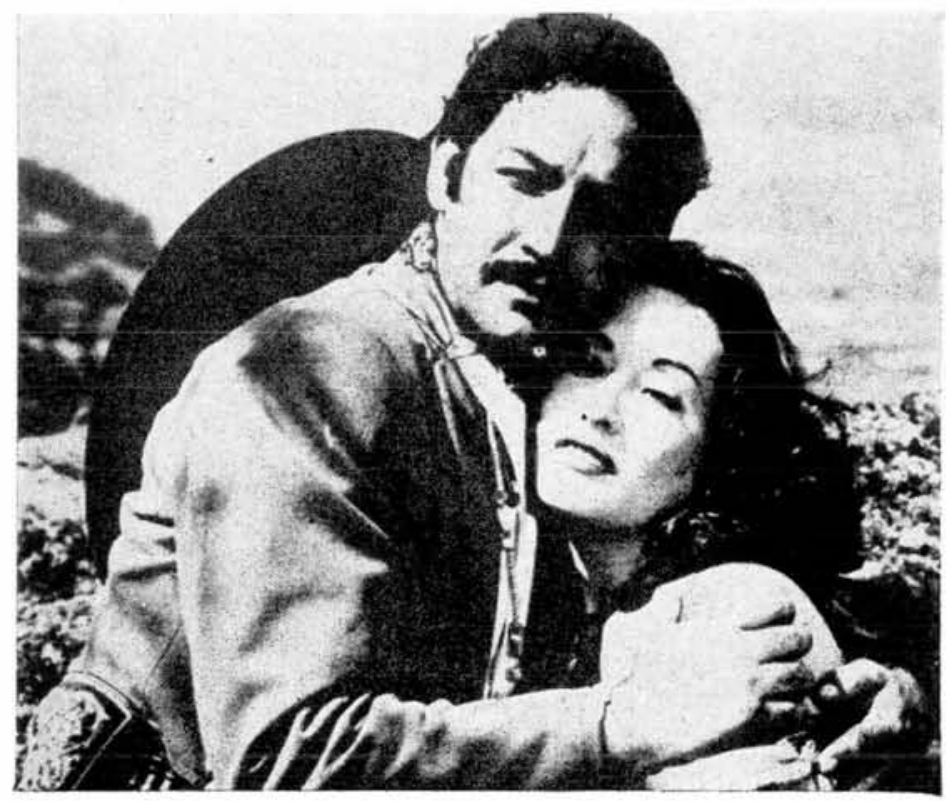

Figura 8. “... Galancs rurales y charros que devendrian en clásicos de la llamada 'Época de Oro' del cine nacional..." Escena de La Madrina del Diablo con Jorge Negrete y Rita Conde (1946). 


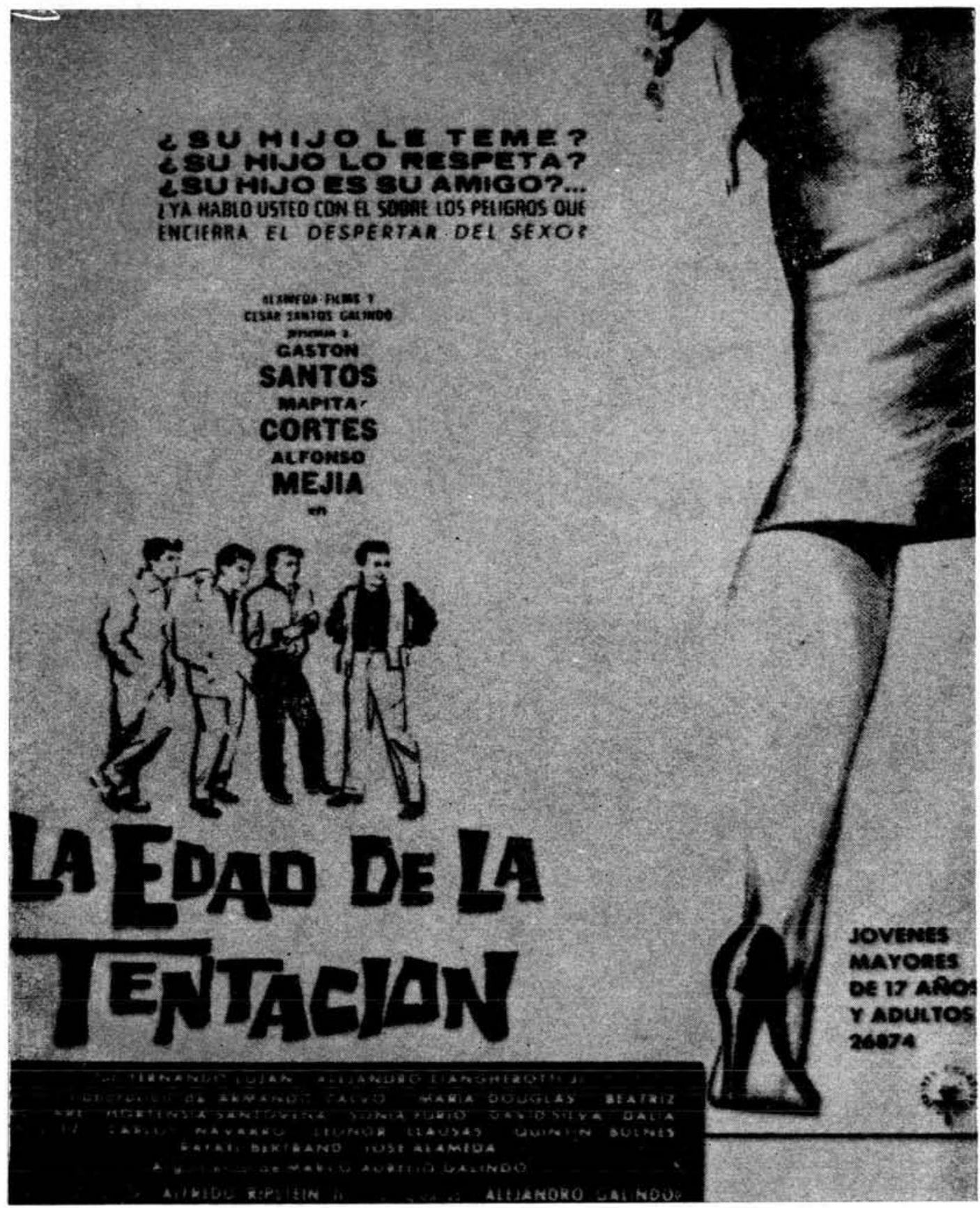

Figura 9. Cartel que anunciaba la cinta $\mathrm{La}$ Edad de la Tentación (1958). 


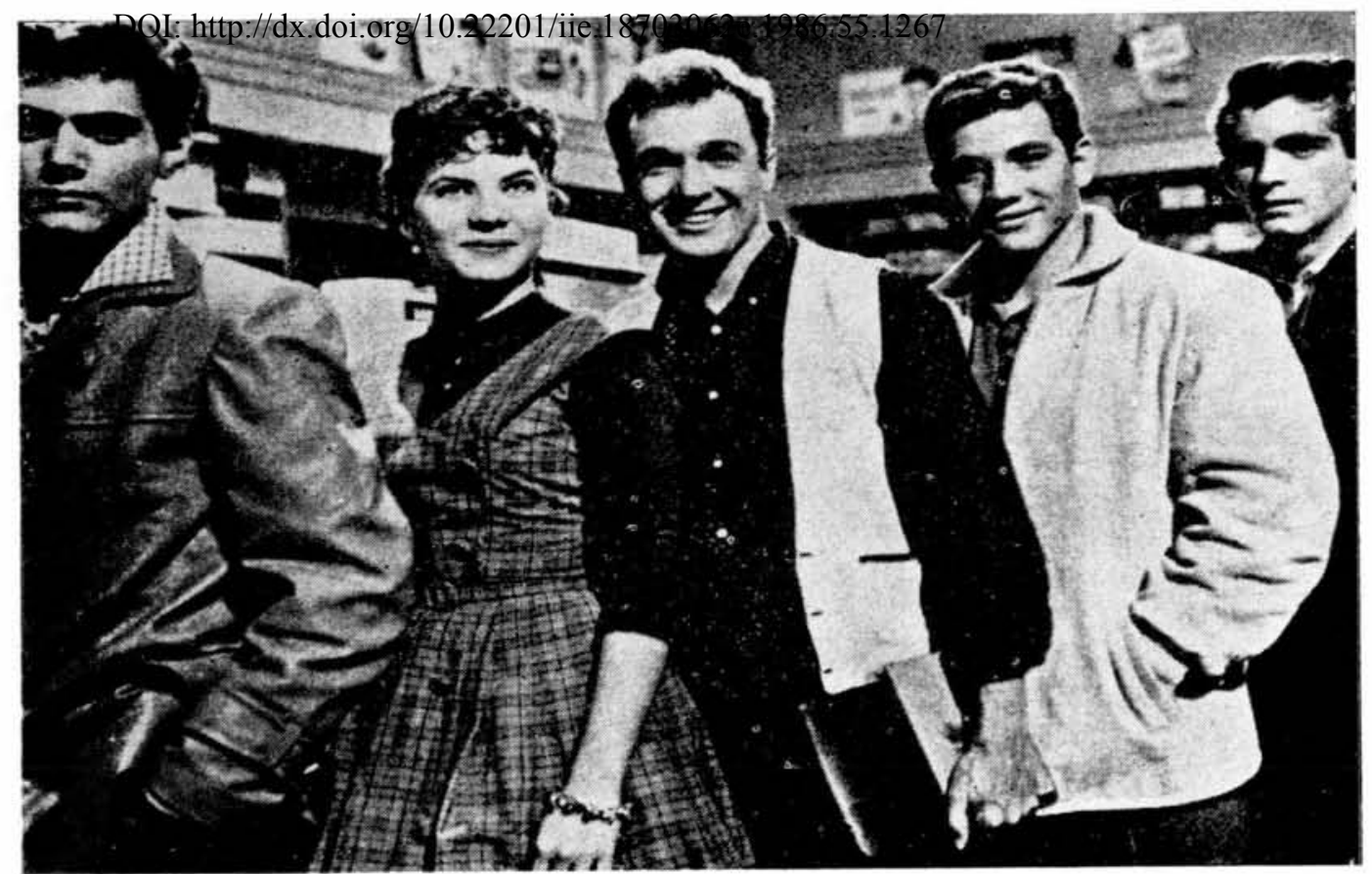

Figura 10. “... Fracasó... por el tratamiento maniqueo y simplista dado a los personajes..." Alejandro Ciangherotti Jr., Gastón Santos, Alfonso Mejía y Fernando Luján, acompañando a Mapita Cortés.

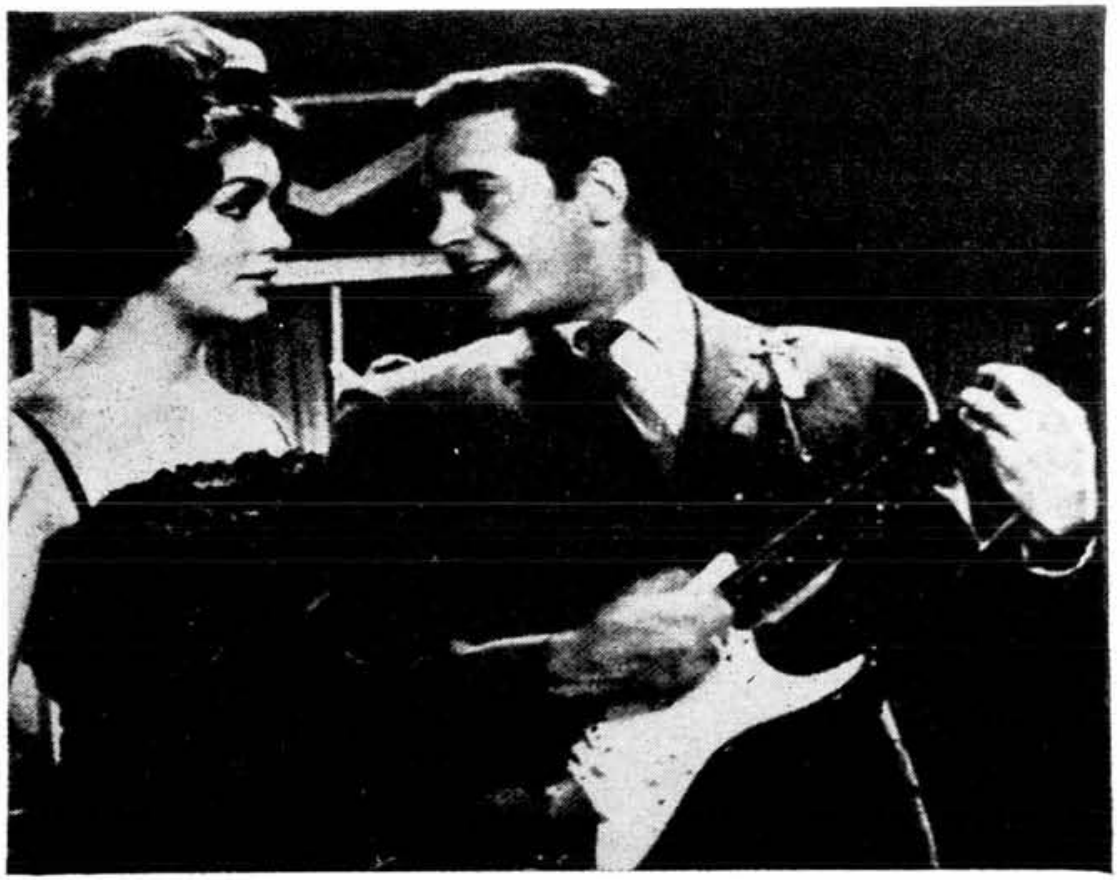

Figura 11. "...El cine mexicano parece no haber sido apto para captar la problemática auténtica de la juventud..." Teresa Velázquez y Julio Alemán en Una Joven de Dieciséis Años (1962). 


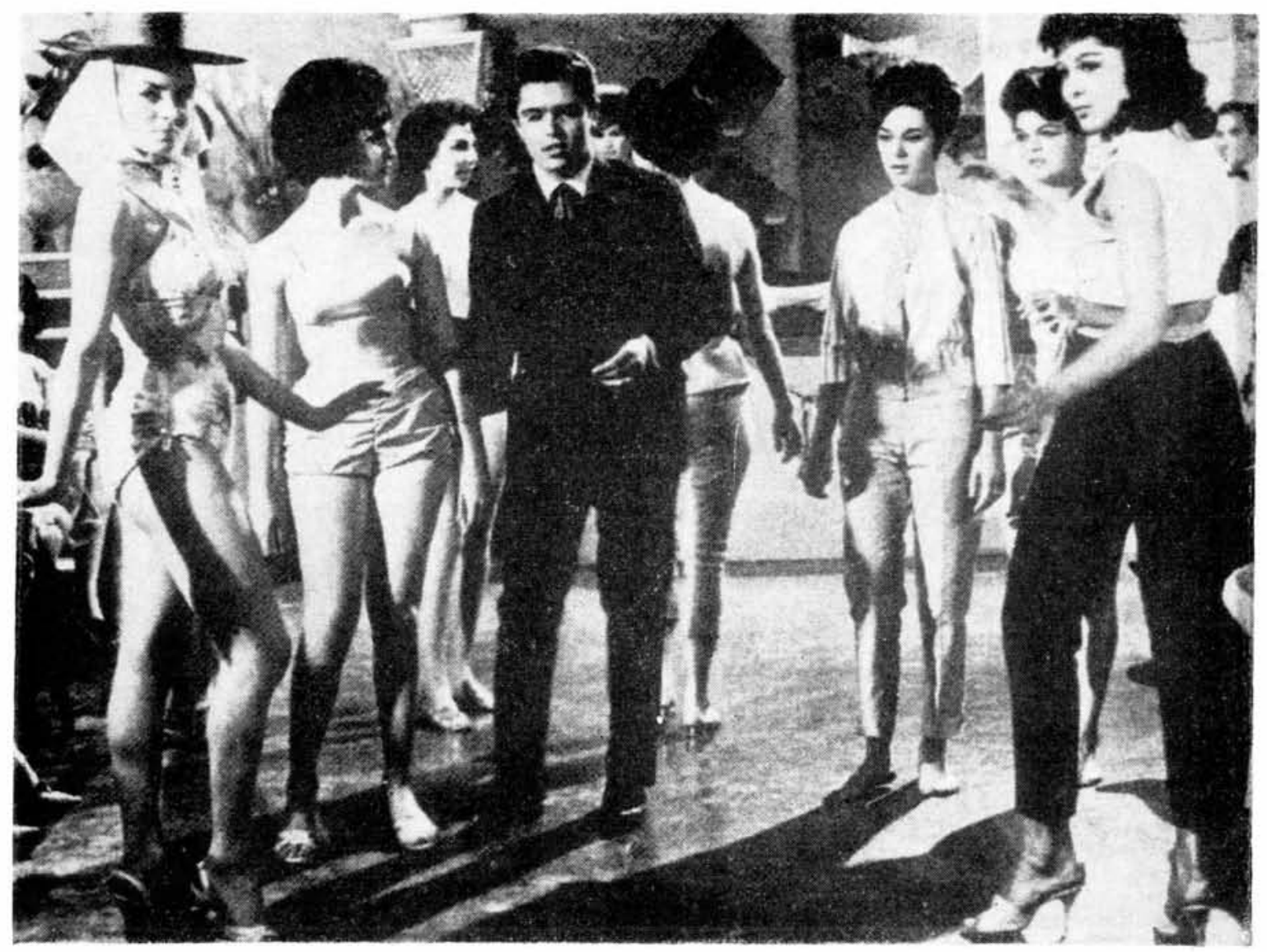

Fizura 12. “... Los máximos idolos mexicanos en esta linea surgirian a principios de los años sesenta y de! ambiente musical..." En la foto Alberto Vázquez en A Ritmo de Twist (1962). 
DOI: http://dx.doi.org/10.22201/iie.18703062e.1986.55.1267 
Los actores más destacados y carismáticos -entre los cuales también predominó el héroe xomántico iradicional- representaron reiterativamente papeles de galanes rurales y charros que devendrían en clásicos de la llamada "spoca de oro" del cine nacional, sin pasar por alto el héroe de barriada no menos popular. Los galanes por antonomasia de estos géneros fueron Jorge Negrete, Pedro Armendáriz y Pedro Infante.

Pero como se puede fácilmente detectar, estos galanes no se caracterizaban por pertenecer al universo de los jóvenes y menos aún, de los adolescentes. Sin embargo, a mediados de la década de los cincuenta, aparece la primera película mexicana con tema de problemática juvenil: ¿Con quién andan nuestras hijas? y con ella, los nuevos galanes del cine mexicano (ver apéndice 2).

\section{Las películas de "rebeldes" en México}

¿Con quién andan nuestras hijas? filmada en 1955, protagonizada en el elenco masculino por Raúl Farell, César del Campo, Freddy Fernández. el "Pichi", Rafael Estrada y Ernesto Alonso, supuestamente "ponía el dedo en la llaga" acerca del problema de la juventud. Pero habría que preguntarsé ¿qué problema?

Es interesante tratar de establecer si este tipo de películas respondió a una problemática juvenil existente o, por el contrario, dicho interés obedeció a un dictado de la moda norteamericana. Ya hemos visto cómo en Estados Unidos surgió primero el fenómeno social de la delincuencia juvenil, que posteriormente fue captado en argumentos cinematográficos; pandilias formadas en la crisis de valores que siguió a la última guerra mundial. Es un hecho que los índices de delincuencia se incrementaron notablemente por estas fechas, síntoma, entre otros, del cuestionamiento implacable que iniciaba la juventud norteamericana contra el establishment -valores, normas, sistemas y todo lo establecido- y que llegaría a su clímax con la flower generation o hippies de los años sesenta.

En México, la generación de los años cincuenta se encontraba en una disyuntiva que podria parecer paradójica: por un lado, la influéncia del escepticismo causado por la Segunda Guerra Mundial, con corolarios como el desencanto, el vacío espiritual, el individualismo a ultranza y la subjetividad, elementos todos de las doctrinas existencialistas; y por el otro, desde un enfoque local, el optimismo causado por la incipiente industrialización favorecida precisamente por los conflictos bélicos inter- 
nacionales. Por ello, existía en México un clima de confianza que hacía concebir al país como Jauja y eran las nuevas generaciones quienes esta. ban llamadas a cosechar un futuro de bonanza. Pero veamos qué imagen proyectó el cine mexicano de aquella época.

¿Con quién andan nuestras hijas? trata de los peligros que amenazan a varias jovencitas de la clase media, cuando intentan desenvolverse por sí mismas y lograr ciertas aspiraciones de independencia y realización personal. En vez de abordar objetivamente los múltiples problemas a que se enfrenta cualquier muchacha en estas condiciones, el film "sermonea" a las jóvenes exagerando peligros tales como seducciones y abusos masculinos, en argumentos que por superficiales y simplistas, no trascienden más allá de la anécdota pueril y folletincesa.

Un comentario de la crítica dice al respecto:

"... (¿Con quién andan nuestras hijas?) Plantea los problemas y los resuelve, dejando una enseñanza a los jóvenes y señalando claramente muchos peligros que deben tener pendientes (sic) los padres que no saben con quién andan sus hijos..." 11

Aunque no se alude a la naturaleza de los peligros, ni tampoco cuáles son dichos problemas, queda por demás explícita la finalidad moralizante de la película: "... dejando una enseñanza a los jóvenes ..." para preservar, en todo caso, el status de una sociedad mojigata y comodina que veía con complacencia la adición del cine a los medios represivos de reforzamiento moral. Ya lo señala Ayala Blanco que "... un cine inescrupulosamente panfletario recuerda a las jovencitas el único deber de su existencia: llegar puras al matrimonio so pena de ser expulsadas de las películas en Mexicolor..." 12

En ese mismo año de 1955 se filma Viva la juventud con Andy Russel y Resortes, cuyo argumento se basa en el tradicional "pique" entre estudiantes del "Poli" y de la "Uni".

El 4 de enero de 1956 se estrenó en el cine Cosmos de la ciudad de México, la cinta Semilla de maldad; el 5 de abril de ese mismo año, Al este del paraiso en el cine de Las Américas y el 26 de julio, en el cine Alameda, la célebre Rebelde sin Causa. A partir de entonces, se dieron dos fenómenos sociales: los efectos didácticos del cine tomaron un sentido inverso al propugnado por las películas mexicanas, provocando una identificación eufórica por parte de los adolescentes con los nuevos héroes

11 Enique Rosado, "Cine crítica", en cine mundial, un Diario diferente, núm. 1125, domingo 1 de abril de 1956, año iv, p. 6 .

12 Jorge Ayala Blanco, citado por E. Gaxcía Riera, op. cit, vol. vi, p. 132, 193. 
que los representaban en las pantallas y que desafiaban, abiertamente, el mundo inconmovible de los mayores. Por otro lado, la producción cine. matográfica mexicana registró una proliferación de cintas con temas juveniles que intentaron emular a las norteamericanas -entre otras causas por el éxito de taquilla que representaban-pero reticentes a abordar los problemas sin tapujos ni prejuicios y con el sentido moralizante que hemos visto, dando por resultado una combinación híbrida y desafortunada.

Así las cosas, en ese año de 1956 se produce "... la más asquerosa película jamás hecha... alarde de repugnante y vil hipocresía moralista ...", 13 que llevó por título Juventud desenfrenada, con Luz María Aguilar, Aída Araceli (quien realizaba "el desnudo más joven del mundo"), Olivia Michel, Xavier Loyá, Antonio de Hud, Alfonso Mejia y dirigida por José Díaz Morales. $\mathrm{El}$ argumento presenta una serie de enredos, problemas y situaciones ficticias tan absurdos y complicados que es inútil transcribir la sinopsis. Lo que queda claro es la falsedad de conceptos e interpretaciones que llevan a esta película a un rotundo fracaso en su intento -si es que lo hubo- por captar la problemática de los jóvenes; fracaso que se hace extensivo a las cintas que le siguieron: ${ }_{\text {¿ } A}$ dónde van nuestros hijos? con Martha Mijares, Carlos Rivas, Carlos Fernández; dirigida por Benito Alazraki en 1956; Los chiflados de rock and roll con Luis Aguilar, Agustín Lara, Pedro Vargas y Piporro (!); La locura del rock and roll con Lilia Prado, Chachita, Juan García Esquivel, Sergio Corona y Alfonso Arau; y Al compás del rock and roll con Martha Roth y Joaquín Cordero, en el mismo año de 1956.

Al año siguiente se filma Cada hijo una cruz, con Demetrio González y Miguel Manzano; Paso a la juventud con Tin Tán, Joaquín Capilla, Elmo Michel, Wolf Rubinsky, Freddy Fernández y Erna Martha Bauman. Seleccioné esta cinta para desglosar su argumento y compararlo con Rebelde sin causa, por ser de las que presenta menos complicaciones en su desarrollo:

El joven Joaquín llega a la capital a estudiar arquitectura y se hace amigo de Casimiro (Tin Tán) fósil de la Facultad de Derecho. Conoce también a Rosa (Erna Martha Bauman) quien lo invita a nadar en el club estudiantil del que su padre es entrenador, Rosa anima a Joaquín para que entrene, ya que el muchacho era en su provincia natal, nadador y clavadista. Rodolfo, ayudante del entrenador, por celos se dedica a 
hostilizar a Joaquín. Casimiro organiza una fiesta en la que competirán orquestas de rock and roll del Politécnico y de la Universidad, en la que se enfrentarán además los campeones de box de ambas instituciones; éstos no son autorizados a pelear a última hora y Casimiro tiene que luchar contra un enmascarado que resulta ser Rodolfo. Por varios incidentes, la pelea se generaliza. Posteriormente, Casimiro quien se encuentra ago biado por las deudas, debe esconder a un tío suyo contrabanclista a quien suponía rico. Con todos estos problemas Joaquín no se prepara debidamente y cbtiene un segundo lugar en los Juegos Panamericanos en una categoría de natación, pero en otra resulta triunfador. Por intrigas de Rodolto se pretende impedir que Joaquín compita en las Olimpiadas de Melbourne, pero gracias a Casimiro, todo se resuelve justo a tiempo para que Joaquín asista al aeropuer to acompañado de Rosa y escoltado por motociclistas, para viajar a Melbourne.

De entrada, salta a la vista la diferente concepción de este argumento y la historia de Ray; mientras que en ésta James Dean representa a un joven común y corriente, en la cinta mexicana el héroe es Joaquín CapiIla, quien acababa de obtener relevantes triunfos para el deporte, y quien interpretaba precisamente a un nadador olímpico. Sin embargo, esta circunstancia que pudo haber sido aprovechada para narrar una historia de superación y coraje, sirvió al guionista para elaborar una complicada trama que rodea al protagonista de múltiples obstáculos de toda índole, menos deportivos. Los personajes son forzados a los cartabones propios de tal o cual actor, como en el caso de Tin Tán como fósil universitario. El pretexto de la supuesta rivalidad entre el IPN y la UNAM sirve para introducir la pelea-rock, elementos indispensables para mostrar el "des. quiciamiento" de la juventud; la forzada pelea de box es otro incongruénte recurso escénico para desplegar la comicidad de Tin Tán y las aptitudes de Rubinsky como luchador. Todo esto, además del maniqueo tratamiento de los personajes, se convierte en clichés demasiado burdos para cumplir un minimo de efectividad en el desarrollo de la película. En fin, mucho se podría añadir al respecto y este ensayo está lejos de pretender hacer critica cinematográfica, pero para los fines del mismo, baste subrayar que las principales divergencias entre ambas cintas consisten en que mientras la norteamericana se basa en el reflejo de una realidad social, la mexicana parte de un esquema ficticio y enajenado.

En el mismo año de 1957 se filmó La rebelión de los adolescentes, con Olivia Michel, Aida Araceli, Alvaro Ortiz, Raúl Farell y Antonio 
de Hud. Desde el títuio, claramente alusivo esta película pretende mostrar los problemas de unos jóvenes inexistentes en nuestro contexto social. García Riera en la obra citada afirma:

... En su afán de anatematizar a unos jóvenes lamentables inventados por ellos mismos, los Calderón (producción) y Díaz Morales (dirección) no lograban ni siquiera la caricatura de la película objeto de sus afanes imitadores, la célebre Rebelde sin causa (1955) de Nicholas Ray, con James Dean... 14

Las siguientes películas filmadas fueron Los hijos del divorcio, con Yolanda Varela, Rafael Bertrand, Amparo Rivelles y Enrique Rambal; El caso de una adolescente, con Martha Mijares y Raúl Farell, que trata la imposibilidad de una joven "decente" para entablar una relación con un muchacho sin peligro de embarazarse y por ende, acarrear la deshonra a los suyos y la infelicidad para sí. El tono de sermón persiste con la consabida moraleja dirigida a las jóvenes de entonces, para que vieran patentemente, lo que les esperaba de acceder a los avances de un Raúl Farell con clara pinta de James Dean.

Por último, filmada en ese mismo año de 1957, Rebelde sin casa, con Tin Tán y sin comentarios.

En 1958 se filma La edad de la tentación con Gastón Santos, Mapita Cortés, Alfonso Mejía, Fernando Luján y Alejandro Ciangherotti Jr. El anuncio de esta película rezaba así:

¿Su hijo le teme? ¿Su hijo lo respeta? ¿Su hijo es su amigo? ¿Ya habló usted con él sobre los peligros que encierra iL DESPERTAR DEL SEXO?

La que pudo haber sido tal vez, una aproximación más lograda en este tipo de películas, fracasó de nuevo por el tratamiento maniqueo y simplista dado a los personajes que los convierte en seres ficticios y acartonados: todos los jóvenes tenían conflictos menos uno, el "muchacho bueno" quien mantenía una comunicación constante con su padre, consistente en asistir en su compañía a conferencias y eventos culturales y piacticar, juntos también, alpinismo en el Popocatépetl.

Éste también es el año de Quinceañera con Martha Mijares, Teresa Velázquez, Maricruz Oliviev, Roberto Cañedo, Raúl Farell, Rita Macedo y Miguel Manzano. Este himno a la cursilería gira en torno a la "ilusión" que tienen todas las jovencitas en la celebración de su decimo-

11 Ibidem, p. 324, 325. 
quinto aniversario. Conociendo la línea de las actrices se puede conjeturar que Martha Mijares hace el papel de muchacha "buena y normal"; Teresa Velázquez es la "frívola y alocada" y Maricruz Olivier será la "conflictiva y mala".

Ellas también son rebeldes se filma en 1959, llevando en el elenco a Lorena Velázquez, Ignacio López Tarso, David Silva, Miguel Manzano y Martha Elena Cervantes "... una joven 'rebelde sin causa' vestida con chamarra a lo James Dean y pantalones a lo Hopalong Cassidy. .." 15

Otras películas filmadas ese año de 1959 fueron Estos años violentos, con Luz María Aguilar; Peligros de juventud, con Elvira Quintana, Teresa Velázquez y Fernando Luján; y Chicas casaderas con Maricruz Olivier y Martha Elena Cervantes.

Sin embargo, hubo intentos serios por rescatar al cine nacional de la comercialización y banalidad en que estaba inmerso; tal fue el caso de dos cintas filmadas en 1960: La joven de Luis Buñuel y Los jóvenes de Luis Alcoriza. La primera entra en el terreno de las excepciones del cine de autor, dado que se trata de Buñuel, cuya obra cinematográfica en México posee una relevancia de sobra conocida. Es una producción mexicano-norteamericana rodada en los Estudios Churubusco durante un mes escaso, de enero a febrero de 1960. Los papeles principales - no se podrían llamar estelares- estuvieron a cargo de actores norteamericanos poco conocidos: Zachary Scott, Bernie Hamilton y Kay Meer Sman; el camarógrafo fue Gabriel Figueroa Buñuel nos muestra en esta cinta diversos aspectos de su propia cosmovisión mediante la historia poco común de una joven que crece en una isla entre dos hombres maduros, donde el aislamiento y la lejania de la "civilización" le confieren códigos morales propios. En el desarrollo de la película "... ningún personaje responde exactamente a las caracterizaciones previas que nuestros propios esquemas ideológicos nos sugieren... La joven es, en resumen, una película importantísima. Si no nos interesa, es muy posible que sea la realidad misma la que no nos interese." 16

Discípulo de Luis Buñuel, Alcoriza debutó como director con la película Los jóvenes. Siguiendo los lineamientos del género y no escapando del todo de los regaños y sermones, este filme representa un "intento serio por desenajenar el tema de la adolescencia en el cine mexicano." 17 Julio Alemán, Teresa Velázquez, Adriana Roel y Rafael del Río son los jóvenes

15 Ibidem, vol, vir, p 274

16 E. García Riera, op cit, vol vIr, p. $340,341$.

17 Jorge Ayala Blanco, La aventura del cine mexicano..., op cit, $\mathrm{p} 181$. 
que luchan y se afanan por encontrax su lugar en el mundo de los adultos, aunque un poco rígidos en los cartabones que les son impuestos, sus cuitas no convencen ni sus victorias emocionan. No obstante, esta película junto con la anterior, logran rebasar la mediocridad seriada propia de la producción cinematográfica de estos años.

\section{Consideraciones finales}

La influencia ejercida en el cine mexicano por los filmes norteamericanos de temática juvenil protagonizados por antihéroes kazanianos, fue en gran medida significativa. Hay que subrayar que casi simultáneamente aparecieron en México las películas y los actores de este género, como hemos visto, ¿Cion quién andan nuestras hijas? se filmó en 1955, el mismo año de la realización de Rebelde sin causa.

Esta influencia se debió, entre otras causas, a la creciente "norteamericanización" que sufría la sociedad mexicana por aquellos años. Ya se ha mencionado cómo en Estados Unidos el heroísmo exaltado de las dos guerras mundiales había devenido en un escepticismo, cuando no cinismo, de una joven generación que cuestionaba el caos del mundo heredado. Es la época del apogeo de las doctrinas existencialistas en Europa que reunían a una bohemia indolente e intensa en los cafés de París, seguidores de Kierkegaard y Sartre y como musa a Juliette Grecó. Esta beat generation pronto se perfiló como gran impugnadora de valores y esquemas establecidos. En Norteamérica los beatniks, las pandillas juveniles y los rebeldes sin causa, son claros antecedentes de los hippies de los años sesenta, con su parafernalia de flores, LSD y "peace and love".

En el aspecto político, se inicia la polarización del orden internacional resultado de los acuerdos de la postguerra, que propiciará la hegemonía de Estados Unidos como potencia del mundo occidental. Como tal, esgrimirá una política expansiva y belicista que la llevó por aquellos años al conflicto con Corea. Debido al creciente antagonismo con la URSS se dio a su vez, un clima de "terror rojo" conocido como Macartismo, que condujo a una "cacería de brujas" anticomunista y a intensificar el control sobre los países latinoamericanos, área "natural" estadunidense. Uno de los organismos que implementaron esta política de intervención cultural fue la Unión Panamericana de la Organización de Estados Americanos.

En México, por lo tanto, dio principio una época de apertura hacia el vecino país del norte, favorecida además por las políticas de Miguel 
Alemán y de Adolfo Ruiz Cortines, que veían en la industrialización y en los modelos de vida norteamericanos, sinónimos de bienestar y progreso. La sociedad mexicana de los años cincuenta entró en un proceso de transformación, acelerado y violento, en el cual pasó de una organización productiva agraria y rural a otra industrial y urbana, con un consiguiente aumento de las clases medias y un crecimiento de las grandes ciudades. Estas clases medias, que vivian alegres y confiadas el llamado "milagro mexicano", no pueden sustraerse a la agobiante cercanía del imperio y, fascinadas por el "american way of life", sufrirán una distorsión paulatina de valores culturales, éticos, sociales y de identidad y serán protagonistas de las nuevas películas que proliferan en el cine nacional. ${ }^{18}$

No hay que pasar por alto que para estos años, el Estado mexicano se encontraba en un proceso de fortalecimiento tal que implicó un debilitamiento del nacionalismo exaltado de los años veinte. Ahora era más importante ser como el mundo moderno, como los países desarrollados que ponian la muestra, por lo que se imponia proyectar, por medio del cine nacional, una imagen moderna y cosmopolita.

Pero en lo referente a las nuevas generaciones, la imagen que dio el cine mexicano no correspondió a la realidad objetiva, ya que la rebeldía no obedeció a las mismas causas que en Estados Unidos.

En México se luchaba entonces por liberarse de moldes demasiado rígidos en lo que a moral se refiere, así como de prejuicios heredados ancestralmente que reprimen y coartan al individuo desde sus primeros años. No es exagerado suponer que la mexicana es una de las sociedades más

Is Acerca de la penettación cultural norteamericana, es interesante lo que consigna México en la cultura en 1955: “... . Hoy, cuando las grandes compañías de Hollywood se han adueñado de múltiples estudios de Europa y controlan la producción y distribudion en gran parte del mundo, toda corriente nacional que defienda su indepen. dencia, su derecho a hacer cine sin trabas del capital extranjero, representa un baluarte del arte cinematográfico... Es un techo que el cine norteamericano está en crisis Las estadísticas lo demuestran. Hollywood (ya en manos de los Rockefeller y los Morgan) ha buscado como paliativo la conquista de otros cines.. ." México en la culluma, núm. 306, enero 30 de 1955.

De igual forma, el siguiente artícalo muestra la intención permanente de las potencias hegemónicas por impedir el desarrollo de una industria cinematográfica propia en los países débiles: “... Reflexiones emitidas... en mayo de 1942 por el tristemente célebre propagandista nazi D. Goebbels... "Yo he ordenado a Greven (productor de cine francés) que venga a verme desde Pards para que reciba mis instrucciones. Es necesario que por el momento los franceses no produzcan sino filmes vacíos... No es necesario en absoluto, desarrollar su nacionalismo... Nuestra política en cine debe ser idéntica a la de Estados Unidos con los continentes sur y norteamericanos... . Debemos tener pror objetivo impedir por todos los medios la creación de toda industria nacional de cine"," México en la cultura, núm. 308, febreio 13 de 1955. 
tradicionales que existen, entendiéndose por tradición un apego a lo establecido, a lo que "ha sido siempre asi", a las creencias, mitos, ritos y costumbres que se heredan de generación en generación. De tal suerte, queda claro que en el despuntar del desarrollismo, implicadas todas sus promesas de modernidad, los jóvenes de entonces tuvieran el anhelo de sex diferentes, más libres para conseguir su lugar en el mundo e intentat adueñarse para sí, de esa realidad moderna y audaz.

No obstante, el cine mexicano parece no haber sido apto para captar la problemática auténtica de la juventud, sino que por el contrario, preocupado como estaba en reproducir fórmulas lucrativas de éxito, no vaciló en forzar modelos importados a que embonaran en el contexto mexicano. En consecuencia, tanto los argumentos como los personajes cayeron en la vacuidad, cuando no en el ridículo, creando algunas aberraciones como las ya mencionadas.

Por lo que toca a los galanes del cine mexicano, no se puede negar que destacaron actores de la talla de Freddy Fernández el "Pichi", Fernando Luján, Alfonso Mejía, Raúl Farell o Alejandro Ciangherotti Jr, pero desafortunadamente ninguno logró situarse más allá de las imitaciones, aunque algunos de ellos continuaron su carrera con éxito. La influencia de Marlon Brando y James Dean parece ser que se limitó a Ios aspectos superficiales, donde se malograron las posibilidades de crear una escuela de actuación seria a cambio de una copia de actitudes y vestimenta. Los máximos ídolos mexicanos en esta línea surgirán a principios de los sesenta y del ambiente musical, representando la versión más acabada de los "rocanroleros": César Costa, Enrique Guzmán y Alberto Vázquez.

Lo que hubo de sincero, de auténtico y por consiguiente, digno de ser rescatado en la generación de los cincuenta y que, no obstante haberse identificado con los ídolos de Hollywood, poseía una personalidad propia, no fue aprovechado por el cina nacional el cual parece haber estado más atento a intereses comerciales que a aspectos cualitativos. A diferencia del estadunidense y con sus muy contadas excepciones, nuestro cine no supo o no pudo reflejar la realidad social, abordando con valor y objetividad la problemática de la época.

Un velo de falsedad, que ha distorsionado la producción cinematográfica, empeñándose en crear imágenes vacías, absurdas y enajenadas, ha sido el constante y principal obstáculo para convertirse en un cine de calidad, canal adecuado de inquietudes y comunicación social, auténtica expresión del arte cinematogrático. 


\section{APENDICE NÚM, 1:}

PRODUCCIÓN CINEMATOGRÁHICA DE ELIA KAZAN (1947-1961)

1947: Boomerang (El justiciero)

1948: Gentlemen's Agreement (La barrera invisible), con Gregory Peck.

1949: Pinky, con Jeanne Graine.

1950: Panic in the Streets (Pánico en las calles).

1951: A Streetcar named Desire (un tranvía llamado deseo), con Vivian Leigh y Marlon Brando.

1952: ¡Viva Zapata! con Marlon Brando y Anthony Quinn.

1953: Man on a Tightrope (Fugitivo del terror rojo).

1954: On the Waterfront (Nido de ratas), con Marlon Brando, Rod Steiger y Eve Marie Saint.

1955: East of Eden (Al este del paraíso), con Julie Harris, James Dean y Raymond Massey.

1956: Baby Doll, con Caroll Baker.

1957: A Face in the Crowd (Un rostro en la multitud), con Patricia O'Neil y Andy Griffith.

1960: Wild River, con Montgomery Clift.

1961: Splendor in the Grass (Esplendor en la hierba), con Nathalie Wood y Warren Beatty

APENDICE NUM 2:

GALANES DEL CINE MEXICANO ANTERIORES A LOS AÑOS CINGUENIA

\begin{tabular}{llll}
\hline Año & \multicolumn{1}{c}{ Actor } & \multicolumn{1}{c}{ Caracterización } & \multicolumn{1}{c}{ Pelicula } \\
\hline 1931 & J J J Martínez Casado & El Jarameño (torero) & Santa \\
1931 & Carlos Orellana & $\begin{array}{l}\text { Hipólito (bohemio) } \\
\text { Marcelino (milita1) }\end{array}$ & Santa \\
1931 & Donald Reed & Santa \\
1933 Alfonso Ortiz Tirado bohemio & Su última canción \\
1933 & Domingo Soler & marinero & La mujer del puerto \\
1934 Ramón Pereda & Diego de la Barrera & Cruz Diablo \\
1934 Emilio Fernández & campesino & Janitzio \\
1935 & Antonio R. Frausto & revolucionario & Vámonos con Pancho Villa \\
1936 & Juan Orol & torero & El calvario de una esposa \\
1936 & Tito Guízar & charro & Allá en el rancho grande \\
1938 José Mojica & militar novohispano & El capitán aventurero \\
1938 Jorge Negrete & charro & Aquí llegó el valentón \\
1938 Emilio Tuero & charro & Juan soldado \\
1938 Pedro Atmendáriz & traje, corbata y sombrero & Una luz en mi camino \\
1939 Tomás Perrín & con frac & Café Concordia
\end{tabular}




\begin{tabular}{|c|c|c|c|}
\hline Año & Actor & Caracterización & Pelicula \\
\hline 1939 & Vicente Padula & gaucho & La justicia de Pancho Villa \\
\hline 1939 & Emilio Tuero & de traje & En tiempos de don Porfirio \\
\hline 1941 & Arturo de Córdova & militar & $\begin{array}{l}\text { ¡Hay qué tiempos, señor } \\
\text { don Simón! }\end{array}$ \\
\hline 1941 & Julián Soler & militar & Simón Bolivar \\
\hline 1941 & Jorge Negrete & charro & ¿Ay Jalisco no te rajes! \\
\hline 1941 & Feriando Soler & $\begin{array}{l}\text { "superhombre que conquista } \\
\text { fama, riqueza, mujeres..." } \\
\text { traje y corbata (G. Riera) }\end{array}$ & El barbero prodigioso \\
\hline 1941 & Pedro Armendáriz & zancheto & Del rancho a la capital \\
\hline 1941 & Arturo de Córdova & espadachín & El conde de Montectisto \\
\hline 1941 & Jorge Negrete & torero & Seda, sangre y sol \\
\hline 1941 & René Caxdona & galán citadino & La casa del rencor \\
\hline 1941 & Arturo de Córdova & galán otoñal & Alejandra \\
\hline 1942 & David Silva & "niño malo" ( $G$. Riera) & Regalo de reyes \\
\hline 1942 & Narciso Busquets & "niño bueno" (G Riera) & Regalo de reyes \\
\hline 1942 & Jorge Negrete & hacendado & Historia de un gran amor \\
\hline 1942 & Ramón Armengod & charro & Amanecer ranchero \\
\hline 1942 & René Cardona & smocking & E1 misterioso señor Marquina \\
\hline 1942 & Antonio Badú & chinaco & La feria de las flores \\
\hline 1942 & Fernando Fernández & chinaco & La feria de las flores \\
\hline $194 ?$ & Pedro Intante & chinaco (debut) & La feria de las flores \\
\hline 1942 & Pedio Armendáriz & $\begin{array}{l}\text { "macho violento, bragado, } \\
\text { bigotón, sombrerudo y ce- } \\
\text { rril" (G. Riera) }\end{array}$ & Soy puro mexicano \\
\hline 1942 & Pedro Infante & revolucionario & Jesusita en Chihuahua \\
\hline 1942 & David Silva & catrín & Soy puro mexicano \\
\hline 1942 & Emilio Tuero & galán citadino & Yo bailé con don Porfirio \\
\hline 1942 & Abel Salazar & $\begin{array}{l}\text { Príncipe Tenoch, galán azte- } \\
\text { ca 〈vestido en consecuencia) }\end{array}$ & La Virgen morena \\
\hline 1942 & Pepe Ortiz & torero & Maravilla del toreo \\
\hline 1942 & Jorge Negrete & héroe tural romántico & El peñón de las ánimas \\
\hline 1942 & Jorge Negrete & charro & Tierra de pasiones \\
\hline 1942 & Ramón Armengod & $\begin{array}{l}\text { "galán romántico y llorón" } \\
\text { (G Riera) }\end{array}$ & Noche de ronda \\
\hline 1943 & Pedıo Armendái iz & charro & Flor Silvestre \\
\hline 1943 & Jorge Negrete & indumentaria siglo xvIII & El jorobado \\
\hline 1943 & Ricardo Montalbán & El Jarameño (torero) & Santa \\
\hline 1943 & $\begin{array}{l}\text { Víctor Manuel } \\
\text { Mendoza }\end{array}$ & Marcelino (militar) & Santa \\
\hline 1943 & Julián Solex & Santos Luzardo (hacendado) I & Doña Bárbara \\
\hline 1943 & David Silva & Mario de Pontmercy & Los miserables \\
\hline 1943 & Emilio Tuero & maestro & Internado para señoritas \\
\hline 1943 & Pedro Infante & campesino & El ametralladora \\
\hline 1949 & Pedro Infante & héroe rural & La mujer que yo perdí \\
\hline
\end{tabular}




\begin{tabular}{llll}
\hline Año & \multicolumn{1}{c}{ Actor } & \multicolumn{1}{c}{ Caracterización } & \multicolumn{1}{c}{ Pelicula } \\
\hline 1948 Crox Alvauado & galán mundano & Doña diabla \\
1948 José Ma Linares Rivas & galán mundano otoñal & Doña diabla \\
1950 & Rubén Rojo & galán citadino & Mala hembra \\
1950 & Fernando Casanova & galán citadino & Ia mujer que yo amé \\
1950 & Pedro Infante & Jurentino Rosas & Sobre las olas \\
\hline
\end{tabular}

Según el cuadro anterior, tomado de material fotográfico de la Historia documental lel cine mexicano de García Riera, tenemos que un $36.8 \%$ corresponde al charro u hombre de campo; un $28.0 \%$ al galán citadino o mundano; un $7.0 \%$ al tenorio de batiada y bohemio y por último, un $280 \%$ a los galanes de carácter. Como se puede fácilmente apreciar, estos galanes no se caracterizan pox pertenecer al universo de los jóvenes y menos aún de los adolescentes.

\section{REFERENCIAS BIBLIOGRAIICAS}

1. Ayala Blanco, Jorge, Aventura del cine mexicano, México, Fd Era, 1968.

2. Brode, Douglas, The Films of the Fifties, Sunset Bouletand to On the Beach, The Citadel Press, Secaucus, N. Jersey, 1980.

3. Ciment, Michel, Elia Kazan por Elia Kazan, Madrid, Ed Fundamento, 1974 (Colección Arre, Serie Cine, No 55).

4. Garcia Riera, Emilio, Historia documental del cine mexicano, 9 tomos, México, Ed. Era, 1969.

5. Griffith, Richard \& Arthur Mayer, The Movies. The sixty-year story of the world of Hollywood and its effect on America, from Pre-nickelodeon days to the present, New York, Simón \& Schuster, 1957.

6. Tailleur, Roger, Elia Kazan, Cinema d'Aujourd'hui, Ed. Seghers, 1966 (No 36$)$.

7. T. T. Thomas, I, James Dean. The real story behind America's mosi popilar idol, New York, Popular Library, 1957.

8. Variety Film Reviews 1954-1958, Volumen IX, Garland Publishing Inc, New York \& London, 1983

\section{REFERENCIAS HEMEROGRAFICAS}

1. Becker, Raymond de, "James Dean, un ejemplo de identificación colectiva", en Novedades, México en la cultura, No 441, 20 de septiembre de 1957.

2. "Histeria morbosa provoca el recuerdo de James Dean", en Excelsior, 1 de octubre de 1956

3. "James Dean, un héroe moderno", Magazine de Novedales, 1956 (Articulo de mi propiedad) 
DOI: http://dx.doi.org/10.22201/iie.18703062e.1986.55.1267

4 "La idolatía por Janes Dean alcanza proporciones alarmantes", en Esto, Sección. B. miércoles 26 de septiembre de 1956.

5. "Ovaciones califica 9 para 'Rebelde sin razón" por Moka, en Ovaciones, 1956 (Artículo de mi propiedad.)

6. Sidney, Frank V, "Vida, arte y muerte de un joven actor", publicado en capítulos en Cine Mundial, septiembre y octubre de 1956.

7 Rosado, Enrique, "Cine crítica", en Cine Mundial, domingo 1 de abril de 1056.

8 Taylor, James, "Sorpresiva versión sobre la muerte de James Dean", en Cine Mundial, lunes 15 de octubre de 1956

9. Tomás, Juan, "James Dean, más animal que humano", en Esto, 1956.

10. Viñals, Luis, "¿Quién era ese extraño que se llamó James Dean?", en Esto, miércoles 8 de agosto de 1956 .

Giudad Universitaria, 7 de marzo de 1985 